\title{
Szállítói finanszírozás vagy bankhitelek? - A magyar vállalatok 2010 és 2015 közötti tanulságai*
}

\author{
Havran Dániel - Kerényi Péter - Víg Attila
}

\begin{abstract}
A tanulmányban azt vizsgáljuk, hogy miként használták a magyar vállalatok a szállítói finanszírozást a 2010 és 2015 közötti időszakban. Burkart és Ellingsen (2004) kereskedelmi hitel elméletét felhasználva 14554 magyar vállalat, (közülük 68 nagyvállalat) paneladatain becsüljük a szállitói finanszírozás és a rövid lejáratú bankhitel kapcsolatát. Jövedelmezöség szerint bontott részmintánkon becsült eredményeink csak a kiegészítő viszonyt erősítik meg. A kapcsolatot a vállalati méretkategóriákra külön is megvizsgáljuk. A kis- és mikrovállalkozások esetén kiegészitő viszonyt találtunk, míg a nagyvállalatoknál helyettesitési hatásra utaló eredményeket kaptunk. A hitelkapacitás-korlátos magyar mikro- és közepes méretü cégek a 2013 utáni idöszakban jellemzően növelték, míg a nem korlátos cégek leginkább szinten tartották a szállítókkal szembeni tartozásaikat.
\end{abstract}

Journal of Economic Literature (JEL) kódok: G32, C23

Kulcsszavak: szállítói finanszírozás, bankhitel-kapacitás, kereskedelmi hitelezés

\section{Bevezetés}

A vállalkozások a kereskedelmi hitelre fontos finanszírozási csatornaként tekintenek, különösen akkor, ha más módon nem képesek forráshoz jutni. A szállítótartozásokból történő finanszírozás gyakran helyettesítője a rövid távú bankhitelezésnek, de az sem kizárt, hogy a bankhitelhez való hozzáférést éppen az segíti elő, hogy a céget jobban ismerő szállítók már hajlandók finanszírozni azt. A gazdasági konjunktúra különböző állapotaiban így egyes cégek a szállítói finanszírozást erőteljesebben, míg mások kevésbé veszik igénybe. Az elmúlt években a magyar vállalkozások egyaránt * Jelen cikk a szerző nézeteit tartalmazza, és nem feltétlenül tükrözi a Magyar Nemzeti Bank hivatalos
álláspontját.

Havran Dániel a Budapesti Corvinus Egyetem egyetemi docense. E-mail: daniel.havran@uni-corvinus.hu Kerényi Péter a Budapesti Corvinus Egyetem Gazdaságinformatika Doktori Iskola PhD-hallgatója, a Pallas Athéné Domus Educationis Alapítvány ösztöndíjasa.E-mail: peter.kerenyi@uni-corvinus.hu Víg Attila a Budapesti Corvinus Egyetem Általános és Kvantitatív Közgazdaságtani Doktori Iskola PhDhallgatója, a Pallas Athéné Domus Educationis Alapítvány ösztöndíjasa. E-mail: attila.vig@uni-corvinus.hu

A szerzők köszönik a Bisnode Magyarország Kft.-nek az adatok rendelkezésre bocsátását.

A magyar nyelvű kézirat első változata 2017. augusztus 9-én érkezett szerkesztőségünkbe.

DOI: http://doi.org/10.25201/HSZ.16.4.86121 
megtapasztalhatták a recessziós, majd az enyhülő finanszírozási környezet időszakát. Dolgozatunkban arra a kérdésre keressük a választ, hogy miként használták finanszírozásra az éves beszámolót készítő (nem pénzügyi és nem közműipari) magyar vállalkozások a szállítókkal szembeni tartozásaikat 2010 és 2015 között.

Erre az időszakra több tanulmány is készült a magyar vállalkozások finanszírozási tevékenységéről, amelyek általában a banki finanszírozási gyakorlatot vagy a hitelkínálat élénkítéseinek hatásait (Növekedési Hitelprogram) vizsgálták (például Csubák - Fejes 2015; Bálint - Fellner 2016, 2017; Bokor - Hidasi 2014; Endrész Harasztosi - Lieli 2015). A szakirodalomban az elmúlt évek tükrében kevés szállítói finanszírozással kapcsolatos vizsgálat született (Szűcs 2008, Nábelek 2016). Márpedig a vállalkozások rövid távú finanszírozási gyakorlatának megértése árnyalhatja, kiegészítheti a hosszú távú hitelezéssel kapcsolatos összképet. Tanulmányunkkal ebben a kérdésben kívánunk hozzájárulni a hazai vállalatfinanszírozási diskurzushoz.

Vizsgálatunknak keresztmetszeti és időbeli vonatkozása is van.

A keresztmetszeti megközelítés során célunk annak feltárása, hogy a vállalatok a bankhitel kiegészítőjeként vagy helyettesítőjeként alkalmazták-e a szállítói finanszírozást a megjelölt időszakban. A kérdés megválaszolásához szükséges gondolati keretet Burkart és Ellingsen (2004) modelljére támaszkodva alakítjuk ki. A cégek szétválasztásához a vállalkozások pénzügyi korlátosságát megtestesítő indexeket - Kaplan-Zingales- ${ }^{1}$, Whited-Wu- ${ }^{2}$, Cleary-index ${ }^{3}$-, valamint a vállalati jövedelmezőséget (alacsony, közepes, magas EBIT/Asset) használjuk, Cunningham (2005) empirikus munkájától eltérően, aki a vállalati „vagyonnal” (belső források vagy önerő nagyságának proxyjával, a profittal) mérte a pénzügyi korlátosságot. Becsléseink csak a kis- és mikrovállalatok körében támasztják alá tisztán az elmélet állításait.

Arra is kíváncsiak vagyunk, hogy vállalatméret-kategóriánként mennyire változik az eredmény. Az általunk kapott empirikus eredmények a magyarországi adatokon többnyire visszaigazolják azt, hogy a nagy- és közepes méretű vállalatoknál a szállítói és a banki finanszírozás között nincs, vagy gyenge helyettesítési, míg a kis- és mikrovállalkozások esetén kiegészítő a viszony. Azt találjuk, hogy a vevőkövetelés jelenléte is növeli a szállítói finanszírozás igénybe vételét, és ez a bankhitel-kapacitásaik korlátján (financially constrained) lévő cégeknél a legerősebb.

A finanszírozási csatornák eltérő viszonya miatt a vállalkozások eltérő módon reagálnak a konjunktúra változásaira. A vizsgált időszakban a szállítói finanszírozás felhasználása egyes cégeknél prociklikus (válságban leépülő, fellendülésben növekvő

\footnotetext{
${ }^{1}$ Kaplan - Zingales (1997)

${ }^{2}$ Whited - Wu (2006)

${ }^{3}$ Cleary (1999)
} 
szállítótartozás), másoknál anticiklikus (válságban elhúzódó, fellendülésben rövidülő szállító forgási idő) mintázatot mutathat. Mondhatjuk-e azt, hogy a válságban tipikus vállalati magatartás a szállítótartozások felhalmozása? Vagy akkor nő inkább a tartozás, amikor ebből finanszírozzák a cégek a fellendülés során a bővülést? $A z$ iparági jelleget leszámítva, mi jellemzi azokat a cégeket, amelyek az első vagy a második csoportba tartoznak? Mekkora volt az ingadozás mértéke az egyes esetekben? A ciklikusság empirikus vizsgálata - bár statisztikailag kevésbé megbízható módon - azt találta, hogy a szállítótartozás fellendülésben való felhalmozása a hitelkorlátos cégekre volt igaz, míg a nem korlátos cégeknél a fellendülés időszakában nem növekedtek a szállító forgási idők. Ezen tendenciák leginkább a kis- és mikrovállalatokra voltak kimutathatók.

A tanulmány további részét a következőképpen építjük fel. Elsőként áttekintjük a magyar vállalkozások általános finanszírozási helyzetét a 2010-2015 közötti időszakban, majd az empirikus elemzést megalapozó elméleti keretet adjuk meg. Ezt követi az adatok és az alkalmazott módszertan bemutatása. Az Eredmények c. részben közöljük a kapott becslések táblázatait, és értelmezzük azokat. A tanulmányt rövid összefoglalással zárjuk.

\section{A szállítók a vállalatfinanszírozás tükrében: 2010-2015}

A kilábalás a 2008-as válságból a magyar vállalkozások számára sokáig elhúzódott, 2012-ben újra elmélyült, csak 2013-2014 jelentett fordulópontot. Egy hitelkorlátos és pesszimista várakozásokkal jellemezhető periódust egy hitelhez való javuló hozzáféréssel és jobb kilátásokkal kecsegtető időszak váltott. Az alábbiakban röviden áttekintjük ezt az időszakot a vállalkozások finanszírozási gyakorlatának tükrében. Elsősorban az mkkv-szegmensre fókuszálunk.

Az 1. ábrán néhány trendet mutatunk be, amelyet az általunk feldolgozott vállalati adatbázison találunk a vizsgált időszakban. (Ezt a NAV által a teljes vállalati körre gyűjtött pénzügyi beszámolókat tartalmazó Bisnode adatbázist az empirikus elemzés során részletesen ismertetjük.) Az ábrákon az egyedi arányokból számított mediánokat jelenítjük meg. 

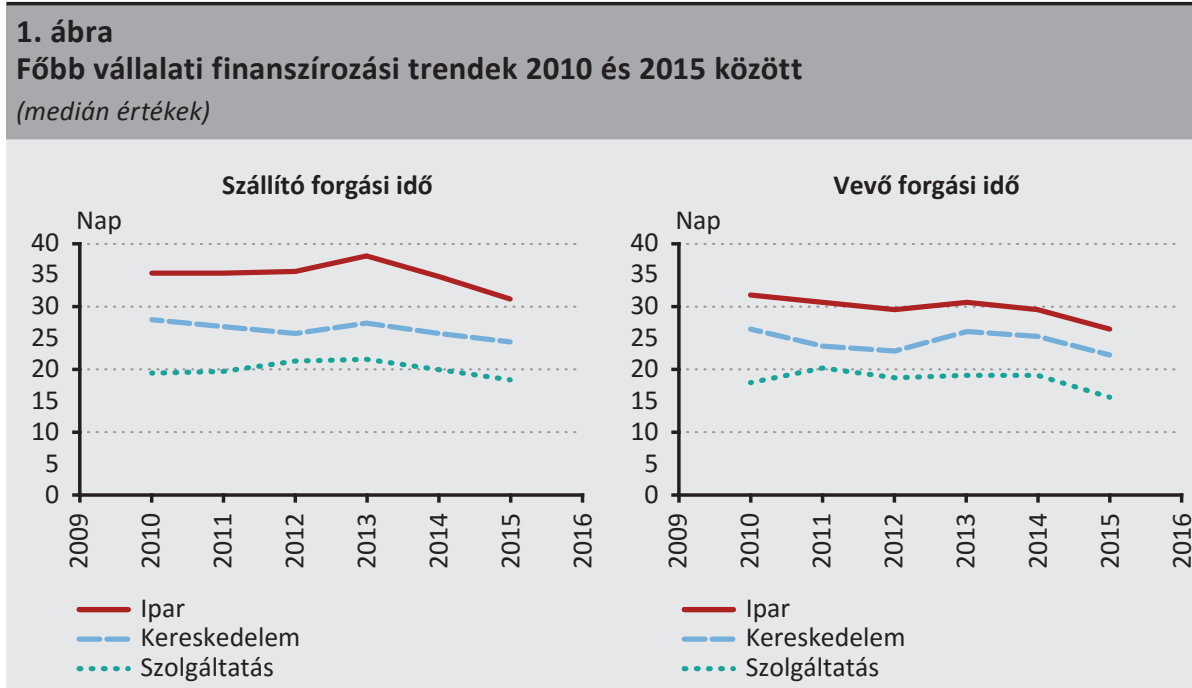

Bankhitel és szállítótartozás

\section{Rövid távú finanszírozási igény}
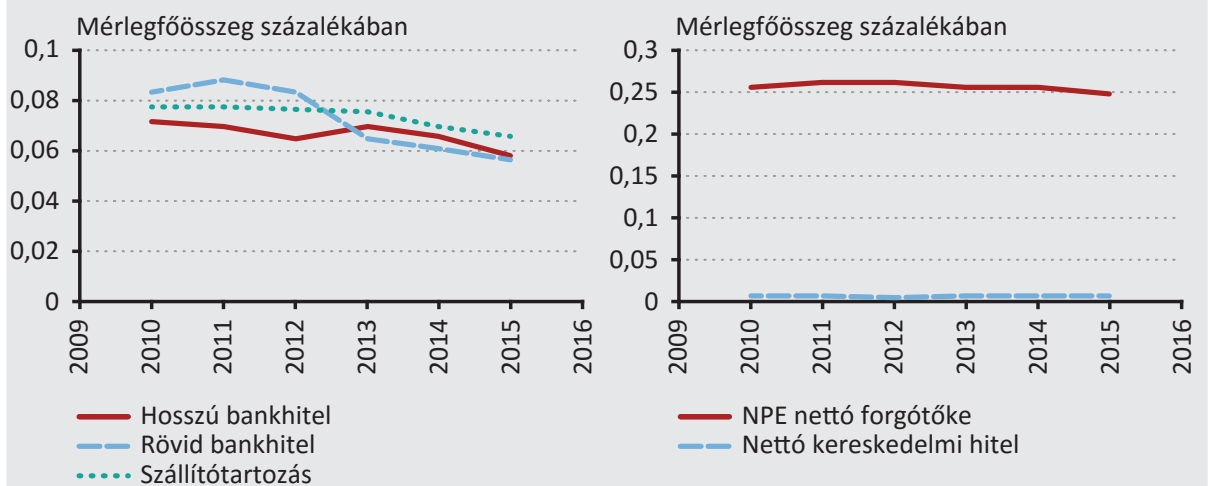

Megjegyzés: Az ábrán szereplő mutatókat a következőképpen készítettük: A szállító forgási időhöz az év végi szállitótartozást az éves anyagjellegű ráfordítások arányában szoroztuk 365-tel, a vevő forgási időhöz az év végi vevőkövetelést az éves árbevétel arányában szoroztuk 365-tel. Az év végi rövid és hosszú lejáratú bankhiteleket, valamint a szállítótartozást a mérlegföösszeghez viszonyítottuk. Nettó kereskedelmi hitelnek hívjuk a vevők mínusz a szállitók különbséget a mérlegfőösszeg arányában, a nem-pénzeszköz (NPE) forgótökének a nem-pénzeszköz forgóeszközök mínusz a szállítók különbséget a mérlegföösszeg arányában.

Forrás: A Bisnode Kft. adatai alapján számítva

A szállítótartozások kiegyenlítésére a kereskedelmi, az ipari és a szolgáltatási szektorban is 2013-ban kellett a legtöbbet várni, majd 2013 után rövidültek a szállító és a vevő forgási idők is. Az időszakban bankhitellel rendelkező cégeknél a rövid lejáratú hitelek mérlegfőösszeghez viszonyított aránya folyamatosan csökkent. A hosszú lejáratú bankhitelek aránya a mérlegben jóval kisebb ütemben, de szintén csökkent. A nem pénzeszköz nettó forgótőke mérlegfőösszeghez viszonyított aránya 25-26 százalék körül, a nettó kereskedelmi hitel mintabeli mediánja 0 százalék körül stag- 
nált. Mindez arra is utal, hogy a vállalkozások vevőktől származó követelésnagyság gyakran együtt mozog a szállítótartozások méretével, valamint a nettó forgótőke elemei közül a készletek okozzák a legnagyobb finanszírozási igényt.

Csubák és Fejes (2014), valamint az MNB (2015) tanulmánya szerint az mkkv-hitelezés volumene a 2008-as csúcsévi szintről (3 896,9 Mrd Ft) 2011-re közel egyharmadával esett vissza (2 753,3 Mrd Ft), majd 2012-ben mintegy 750 Mrd Ft-tal emelkedett. Az ugyanezen időszakban készült SAFE jelentések (SAFE 2011, 2013, 2014, 2015) kifejtik, hogy a külső forrásokhoz való hozzájutás a kis- és közepes méretű vállalkozások számára 2011-ben jelentett leginkább problémát, majd folyamatosan javulónak ítélték meg a vállalkozások a helyzetet. Ezzel párhuzamosan egyre több nehézséggel járt képzett munkaerőt találni, miközben a piaci versenyt mint fő kihívást egyre kevésbé jelölték meg a válaszadók. A válaszokat az 1. táblázatban foglaljuk össze. A kérdőívekre adott válaszokból az is kiderült, hogy 2013-tól 2015ig csökkent azon válaszadók aránya, akiknek finanszírozási kérelmét elutasították. Az európai országok körében készített kérdőíveket Magyarországon viszonylag kicsi mintákon kérdezték le, ezért óvatosan kell kezelni a feltárt attitűdökre kapott arányokat.

\begin{tabular}{|c|c|c|c|c|c|}
\hline \multicolumn{6}{|l|}{$\begin{array}{l}\text { 1. táblázat } \\
\text { Fő kihívások a magyar KKV-knál } \\
\text { (SAFE kérdőives felmérések) }\end{array}$} \\
\hline $\begin{array}{l}\text { Jelenleg melyik probléma jelenti a cége } \\
\text { számára a legnagyobb } \\
\text { kihívást? }\end{array}$ & 2009 & 2011 & 2013 & 2014 & 2015 \\
\hline Vevőket találni & $43,50 \%$ & $24,80 \%$ & $18,90 \%$ & $16,22 \%$ & $26,14 \%$ \\
\hline Verseny a piacon & $1,70 \%$ & $23,50 \%$ & $17,10 \%$ & $14,51 \%$ & $9,57 \%$ \\
\hline Finanszírozáshoz való hozzáférés & $18,70 \%$ & $22,00 \%$ & $17,30 \%$ & $14,06 \%$ & $11,29 \%$ \\
\hline Munkaerő vagy a termelés költségei & $3,10 \%$ & $6,10 \%$ & $11,90 \%$ & $10,73 \%$ & $12,37 \%$ \\
\hline Képzett munkaerőt találni & $4,20 \%$ & $6,60 \%$ & $10,90 \%$ & $18,36 \%$ & $21,93 \%$ \\
\hline Szabályozási környezet & $12,40 \%$ & $10,90 \%$ & $11,20 \%$ & $14,68 \%$ & $9,33 \%$ \\
\hline Egyéb & $16,40 \%$ & $6,10 \%$ & $12,70 \%$ & $11,44 \%$ & $9,37 \%$ \\
\hline
\end{tabular}

Forrás: SAFE (2011, 2013, 2014, 2015) kérdőíves felmérések adatai

Az MNB hitelezési folyamatokat követő jelentései (Bálint - Fellner 2016, 2017) is megerősítik a vállalatok által érzékelt tendenciát: a vállalkozások banki hitelezési feltételei 2013-tól jelentősen javultak. A tanulmány szerint a hitelkamat és forrásköltségek közötti különbség is csökkent, a fedezeti követelmény, valamint a megkövetelt hitelképességi szint enyhült, a felvehető hitelkeret bővült. 2013 júniusától a támogatott hiteleknek (elsősorban a Növekedési Hitelprogramoknak - a továbbiakban: NHP) jelentős volt a szerepe a finanszírozáshoz való hozzáférésben. Míg az első szakasz elsősorban a hitelkiváltásról szólt, addig a 2013 őszén induló második 
szakasz már a forgóeszköz- és a beruházási hitelekhez jutás feltételeiben is javulást eredményezett. (Az NHP harmadik, 2016-os szakasza már nem tartozik az elemzett periódusba.) Az időszak fejleményeit Módos, Bokor és Hidasi (2014), valamint Bokor, Fellner és Plajner (2014) értékeli, az NHP-program hatását a beruházásokra pedig Endrész, Harasztosi és Lieli (2015) elemzi.

Míg az egyértelműen megfogalmazható, hogy a finanszírozási lehetőségek javultak a 2013-2015-ös időszak alatt, addig a finanszírozás iránti kereslet alakulása ennél lehangolóbb képet mutat. A finanszírozás iránti keresletet az értékesítési lehetőségek és a növekedési várakozások határozták meg leginkább. A GVI 2015. januári KKV Körkép felvételéből (Nyírő és Hajdu 2015) kiderül, hogy a konjunktúramutatók egybehangzóan 2009 nyarát, valamint 2012 nyarát azonosítják a két mélypontnak, 2013-tól azonban a várakozások jelentősen javultak. A várakozásokban történő változás a válság előtti hangulat elérését jelentette, de a vállalkozások a válság előtti szinthez mérve növekedést még nem tudtak felmutatni - állapítja meg Juhász és Reszegi (2017). Összességében, a recessziós hatások eltűnése után nőtt a finanszírozási kereslet, de mindez a korábbi szintre való visszaállást jelentette a növekedésből jelentkező finanszírozási igény bővülése nélkül. A már említett Bálint és Fellner (2017) jelentés a hitelkereslet alakulását is megvizsgálta. A szerzők leírják, hogy míg a hosszú távú hitelek iránti kereslet 2010-től 2013-ig jelentősen csökkent, majd újra erősödött, addig a rövid lejáratú bankhitelek keresletében tipikus tendenciák nem voltak tetten érhetők. Mindezek eredőjeként az egyes negyedévekben negatív volt a hosszú lejáratú vállalati hitelállomány növekedési üteme 2010 év eleje és 2013 első féléve között, de 2013 második félévétől javult a helyzet, bár jelentős növekedés ekkor sem alakult ki. Már a megfigyelt időszak előtt is jellemző volt (főleg az építőiparban és az 50 főnél kevesebbet foglalkoztató cégek körében) a lánctartozás (Szücs 2008), amely 2016-ig sem tűnt el. Ezek a tartozások általában késedelemben lévő szállítótartozásoknak minősültek, sokuk pedig a beszállítók szempontjából kétes követelésnek is. A GVI által készített felmérés szerint (Nábelek 2016) a 2014-es évben javult kiemelkedően nagyot a fizetési morál.

A SAFE (2015) felmérésben válaszadók 21,6 százaléka használta az elmúlt hat hónapban a rövid lejáratú banki finanszírozást (hitelkeret, folyószámlahitel, hitelkártya), valamint a válaszadók 44 százaléka ítélte meg általában is relevánsnak üzletmenete szempontjából ezt a csatornát. A lízing számított a második legnépszerűbb finanszírozási formának: 14,2 százalék használta a közelmúltban, és 37,7 százalék tartotta relevánsnak. A támogatott banki hiteleket, valamint a pályázatokat együttesen a válaszadók 8,9 százaléka használta ezen időszak alatt, és 29,3 százaléka szerint fontos is. Nem támogatott bankhiteleket a válaszadók 6,7 százaléka, egyéb hiteleket 8,4 százaléka használt a féléves időhorizonton. A kereskedelmi hitelt a válaszadók kevésbé használták (4,3 százalék) és kevésbé is tartották fontosnak (a válaszadók 13,22 százaléka), mint az előző csatornákat. A faktoring használatát még ennél is 
kevesebben jelezték. A finanszírozást tárgyieszköz-beruházásra, valamint készletbeszerzésre használták az MNB hitelintézeti adatokon alapuló Pénzügyi Stabilitási Jelentése (MNB 2017) szerint.

Bár az idézett tanulmányok némelyike a fordulópontot kicsit vagy előbbre, vagy későbbre helyezi a vizsgálati fókuszok, időszakok és minták eltérősége miatt, öszszességében a finanszírozáshoz való hozzáférés a 2013-as év második felétől kezdve javult. A bankszektorban emelkedett a folyósított hitelek volumene, de a cégszintű hosszú lejáratú bankhitelek/mérlegfőösszeg arány nem változott jelentősen. A szállítói finanszírozást 2013-ban vették igénybe leginkább. Bár a kereskedelmi hitelt nem sorolták a legfontosabb külső források közé, az adatok alapján úgy látszik, hogy rövid távon lényeges eleme volt a hazai vállalatok múködésének.

\section{Elméleti keret}

A szállítói finanszírozásnak különféle egyedi motivációi lehetnek. A kereskedelmi hitelezés okait feltáró elméleteket Petersen és Rajan (1996) három motívum köré rendezi: (1) a finanszírozási módból fakadó speciális előnyök (monitoring, beszállítói alkuerő, eszközfedezet), (2) árdiszkrimináció, valamint (3) tranzakciós költségek.

A finanszírozási módhoz tartozó előnyök (1) három különböző érvelésre épülnek. A monitoringon alapuló érvelés szerint a szállítónak a beszállítási kapcsolat révén több és pontosabb információja, jobb nyomon követési lehetősége lehet más finanszírozókhoz képest (Emery 1984, Smith 1987, Freixas 1993, Biais és Gollier 1997). A beszállítói alkuerővel érvelők szerint a szállító - helyzetéből adódóan - könynyebben tudja befolyásolni, esetleg sakkban tartani a vevőjét azzal, hogy a jövőbeli szállításokról képes dönteni. Az eszközfedezeti előnnyel érvelő magyarázatokban a cég számára a szállítótól szerzett forgóeszközök fedezetként szolgálhatnak fizetési mulasztás esetén, mely felhasználási lehetőség nem jelentkezik a pénzben kapott kölcsön során. Az árdiszkriminációs (2) megközelítésben a szállító szempontjából írják le a jelenséget: Schwartz (1974) a szállítói finanszírozást a szállító árazási politikájaként értelmezi, Brennan, Maksimovic és Zechner (1988) pedig kifejti, hogy a szállítók az árra érzékenyebb vevőik számára rugalmasabb fizetési feltételeket szabhatnak, aminek segítségével árdiszkriminációt alkalmaznak. A tranzakciós költség alapú (3) magyarázatok fő képviselője Ferris (1981), aki a kereskedelmi hitel jelenlétét azzal indokolja, hogy mind a vevő, mind pedig a szállító számára a fizetési tranzakciók lebonyolítása olcsóbb lehet, ha a pénzügyi teljesítés csak időszakosan (például havonta, negyedévente) történik.

Burkart és Ellingsen (2004) modellje átfogó módon írja le annak elméletét, hogy miért használják a kereskedelmi hitelezést másfajta finanszírozással szemben a vállalatok. A modellben a vállalkozók bank és szállító segítségével is finanszírozhatják magukat, azonban mindkét finanszírozási forma esetén fennáll az aszimmetrikus 
információs viszony a vállalat és a finanszírozó között, ami korlátot szab a finanszírozásnak. A modellben a bank kevésbé ismeri a vállalatot, mint a szállító, így a bankhitelezés során a vállalkozó szigorúbb korláttal szembesül. Ez azt jelenti, hogy a jobb ismeretség miatt a vállalkozó még akkor is képes a szállítófinanszírozást igénybe venni, amikor a bankhitelhez egyébként már nem férne hozzá. További különbség, hogy a bankhitelezés esetén a vállalkozó készpénzt, a szállítói finanszírozás során pedig a termeléshez felhasználható forgóeszközt kap. Míg a készpénzt a vállalkozó könnyen magáncélokra fordíthatja, addig a kevésbé likvid forgóeszközt nehezebb eltulajdonítania. Ennek egy lehetséges következménye, hogy nagy információs aszimmetria mellett egy cégnek érdemes a szállítókkal szemben eladósodni és ezzel eszközöket szerezni, hogy az így szerzett fedezetképességgel már a bankhitelt is megszerezhesse. Burkart és Ellingsen ezt az esetet jelöli meg, amikor a szállítói finanszírozás kiegészítője lehet a bankhitelezésnek.

A banki és szállítói finanszírozás közötti viszonyt Nilsen (2002) amerikai, Cunningham (2005) kanadai, Ying, Guo és Yang (2014) pedig kínai vállalatok körében vizsgálta empirikusan. Eredményeik legtöbbször összecsengenek Burkart és Ellingsen elméletével. Burkart és Ellingsen a szállítói finanszírozásra mint 1-3 hónapos időtávú, de meghosszabbítható, a bankhitelre pedig tipikusan 1-3 éves időtávú forrásként tekintett. Az elmélet tehát elsősorban a rövid távú forrásokra szorítkozik. Arra a kérdésre, hogy a hosszú lejáratú bankhitel milyen viszonyban áll a szállítói finanszírozással, Fazzari és Petersen (1993) ad választ amerikai vállalati adatokon való vizsgálatával. A szerzőpáros arra a megfigyelésre jutott, hogy a befektetett eszközökbe való beruházás, valamint a nettó forgótőke egymással versenyez a forrásért, így a hosszú távú bankhitel és a szállítói finanszírozás között is lehetséges a helyettesítési viszony. Ferrando és Mulier (2013) azt találja, hogy a szállítói finanszírozás a növekedésnek is fontos forrása lehet.

A szállítói és a banki finanszírozási döntésre a cég vevőinek finanszírozása is jelentős hatással bírhat. Azon cégeknek, amelyek szállítótartozásukat képesek növelni, nagyobb terük lesz vevőiket árdiszkriminációs célból finanszírozni. A vevőkövetelés ráadásul kevésbé likvid, mint a készpénz, és a fedezettöbblet javíthatja a banki hitelkapacitást is. Európai vállalatokra García-Teruel és Martínez-Solano (2010) elemezte a szállítói finanszírozás összetevőit, akiknek eredményei többek között az árdiszkriminációs elméletet erősítette meg.

A készletezési döntések is szerepet játszhatnak a szállítói finanszírozás használatában - mutatja meg egy elméleti modell segítségével Bougheas, Mateut és Mizen (2007), akik az Egyesült Királyságban múködő vállalatokra tesztelik empirikusan is mindezt. Chittenden és Bragg (1997) három ország mintáin (Németország, Franciaoszág, UK) is megerősíti a készlettartás és a szállítótartozások közötti összefüggést. A készpénztartást tekintve Kling, Paul és Gonis (2014) szintén az Egyesült Királyság-beli 
cégek adatait elemezve azt találja, hogy a nagyobb készpénzarány javítja a szállítói finanszírozáshoz való hozzáférést.

Empirikus vizsgálatunkhoz Burkart és Ellingsen (2004) alábbi következtetéseit hívjuk elő:

1) A pénzügyileg nem korlátos (bankhitel- és kereskedelmihitel-kapacitásukat el nem érő) cégek esetén a rövid távú bankhitel és a szállítói finanszírozás között nem áll fenn egyértelmű kapcsolat az elmélet alapján.

2) A pénzügyileg korlátos (bankhitel-kapacitásukat kimerítő) cégek esetén,

a) kereskedelmihitel-kapacitásukat el nem érő vállalatok esetén helyettesítési,

b) kereskedelmihitel-kapacitásukat kimerítő cégek esetén kiegészítő viszony áll fenn a rövid lejáratú bankhitel és a szállítói finanszírozás között.

A következményeket kiterjeszthetjük a konjunktúrával kapcsolatosan is. Amennyiben a bankhitel nagysága prociklikusan alakulna az időben egy cégnél (a korlátosság jegyeit mutatja), akkor

- a szállítói finanszírozás anticiklikus jelleget mutatna a 2a) esetben,

- a szállítói finanszírozás prociklikusan alakulna az időben a 2b) esetben.

A kereskedelmi hitelezés érzékenysége az üzleti ciklusokra ezért eltérően alakulhat attól függően, hogy milyen mértékű a szállítói és a banki finanszírozás kapacitáskorlátja. A szerzők a cég számára rendelkezésre álló vagyont (önerőt) jelölik meg, mint a kapacitáskorlátok elérését befolyásoló tényezőt. A kis önerővel rendelkező cégek mind bank-, mind kereskedelmi hitelben, a közepes önerővel rendelkező cégek csak bankhitelben korlátosak, a nagy önerővel rendelkező cégek nem használják ki kapacitásaikat egyik formában sem.

Első vizsgálatunk során a szállítótartozás és a rövid, valamint a hosszú lejáratú hitelezés kapcsolatát derítjük fel. Arra is kitérünk, hogy a vevőállomány hogyan hat a szállítótartozásra. Második kérdésünk, hogy az önerőt a vállalatok átlagos jövedelmezőségével, a banki kapacitás korlátait pedig néhány, a szakirodalomban elterjedt módon megragadva (Kaplan-Zingales-, Whited-Wu- és Cleary-indexekkel) kapunk-e az elméleti következtetésekhez hasonló mintázatokat. A gyakorlatban a kereskedelmi hitel kapacitását sok más tényező is befolyásolhatja belső forráson kívül. Amennyiben a vállalatnak nagyobb a szállítóval szembeni alkuereje, akkor sokkal nagyobb kereskedelmihitel-kapacitásai lehetnek. Ezért a harmadik lépésben megvizsgáljuk, hogy a vállalati méret szerint mennyire tér el a bankhitel-szállítói finanszírozás viszonya. Negyedik (kiegészítő) lépésként a szállítótartozások időbeli viselkedését jellemezzük. 


\section{Adatok és módszertan}

Az adatokat a Bisnode Magyarország Kft. bocsátotta rendelkezésünkre. A nyers adatbázisban az összes kettős könyvelést végző és a NAV-nak éves beszámolót készítő magyar vállalkozás szerepel. Ezekből az éves beszámolót forintban készítő, nem pénzügyi (TEÁOR 6400-6699), valamint nem közműszolgáltató (TEÁOR 3500-3799) magyar vállalkozásokat vizsgáljuk 2010 és 2015 között. Az egyszerűsített éves beszámolót, valamint a mikrovállalkozások számára fenntartott beszámoló típust készítő cégeket a minta nem tartalmazza. Bár ez utóbbi cégek számossága magas, gazdaságban betöltött méretük jócskán elmarad az éves beszámolót benyújtó cégek csoportjától, így a használt adathalmaz makrosúlya jelentősnek minősíthető. Az adatok tisztítása során a közgazdaságilag nem értelmes, illetve hibás tételeket (mint például negatív mérlegfőösszeg vagy más negatív mérlegtételek) mutató cégeket elhagytuk, és ahol hiányzó és nem pótolható adatokat találtunk (mint például hiányzó eredménykimutatás), azokat a vállalat-év megfigyeléseket elhagytuk. Mindezeket követően az elemzett adatok körébe azon cégek kerültek be, amelyek legalább 3 éven keresztül folytatólagosan rendelkeztek mérleggel és eredménykimutatással az adatbázisban.

Ez összesen 14554 darab céget jelent, amelyben az árbevétel európai uniós besorolása alapján az adathalmazban 68 nagyvállalat, 1332 közepes méretű vállalat, 4 354 kisvállalat és 8800 darab mikrovállalkozás kapott helyet. A pénzügyi és a közműszolgáltató cégeket leszámítva (amelyek más üzleti logikával működnek) így az összes olyan magyarországi vállalat szerepel az adatbázisunkban, amelyre a NAV rendelkezik adatokkal, és az adatok minősége megfelelő. A mintán belüli árbevétel-megoszlások szerint a nagyvállalatok árbevétele kb. 10 százalék, a középvállalatoké 46 százalék, a kisvállalatoké 37 százalék, a mikrovállalkozások árbevétele pedig 7 százalékot tesz ki az összesített árbevételből.

\section{2. táblázat}

A megfigyelések száma évenként az egyes szektorokban

\begin{tabular}{l|c|c|c|c|c|c} 
& $\mathbf{2 0 1 0}$ & $\mathbf{2 0 1 1}$ & $\mathbf{2 0 1 2}$ & $\mathbf{2 0 1 3}$ & $\mathbf{2 0 1 4}$ & $\mathbf{2 0 1 5}$ \\
\hline Kereskedelem & 3190 & 3375 & 3547 & 3215 & 2918 & 1710 \\
\hline Ipar & 4372 & 4594 & 4773 & 4418 & 4079 & 2502 \\
\hline Szolgáltatás & 5167 & 5616 & 5840 & 5188 & 4557 & 2507 \\
\hline Összesen & 12729 & 13585 & 14160 & 12821 & 11554 & 6719 \\
\hline
\end{tabular}

Megjegyzés: A szerzők számítása a vizsgált mintán.

A mintában összesen 3665 társaság a kereskedelmi szektorban, 4896 cég az ipari szektorban, 5993 vállalkozás pedig a szolgáltató szektorban múködött a TEÁOR-kódok szerinti klasszifikáció alapján (2. táblázat). A 2015-ös évet leszámítva (ahol nem állt még rendelkezésünkre az összes vállalkozás beszámolója) az adatbázis átlagosan 12-13 ezer vállalkozás adatait foglalja össze, az új belépők és a kilépők aránya is alacsony. 


\begin{tabular}{|c|c|}
\hline $\begin{array}{l}\text { 3. táblázat } \\
\text { A változók elnevezés }\end{array}$ & \\
\hline ACCOUNTS_PAYABLE: & Tartozások áruszállításból és igénybe vett szolgáltatásból (Szállítók) \\
\hline ACCOUNTS_RECEIVABLE: & Követelések áruszállításból és szolgáltatásból (Vevők) \\
\hline ST_LOANS: & Rövid lejáratú hitelek \\
\hline LT_LOANS: & Beruházási és fejlesztési hitelek \\
\hline ASSET: & Mérlegfőösszeg (a regressziókban ennek logaritmusát használjuk: LOGASSET) \\
\hline SALES: & Értékesítés nettó árbevétele \\
\hline AP_SALES: & Szállítók / Értékesítés nettó árbevétele \\
\hline AR_SALES: & Vevők / Értékesítés nettó árbevétele \\
\hline EBIT_SALES: & Üzemi (üzleti) eredmény / Értékesítés nettó árbevétele \\
\hline ST_LOANS_SALES: & Rövid lejáratú hitelek / Értékesítés nettó árbevétele \\
\hline LT_LOANS_SALES: & Beruházási és fejlesztési hitelek / Értékesítés nettó árbevétele \\
\hline LEVERAGE: & $\begin{array}{l}\text { (Rövid lejáratú kötelezettségek + Hosszú lejáratú kötelezettségek) / } \\
\text { Mérlegfőösszeg }\end{array}$ \\
\hline CURRENT: & Forgóeszközök / Rövid lejáratú kötelezettségek \\
\hline CASH_SALES: & (Pénzeszközök + Értékpapírok) / Értékesítés nettó árbevétele \\
\hline INTEREST_COV: & $\begin{array}{l}\text { Kamatfedezettségi mutató: Üzemi (üzleti) eredmény / } \\
\text { (Fizetett kamat és kamatjellegú ráf. + Jóváhagyott osztalék, részesedés) }\end{array}$ \\
\hline CAPEX_SALES: & $\begin{array}{l}\text { (Befektetett eszközök ÁV - Értékcsökkenés) / } \\
\text { Értékesítés nettó árbevétele }\end{array}$ \\
\hline SALES_GROWTH: & Az árbevétel növekedési üteme az előző év százalékában \\
\hline PROFIT_SALES & Adózott eredmény ${ }_{\mathrm{t}} /$ Árbevétel $_{\mathrm{t}-1}$ \\
\hline ROE: & Adózott eredmény ${ }_{t} /$ Saját tőke $_{t-1}$ \\
\hline ROIC: & $\begin{array}{l}\text { NOPLAT }_{t} / I_{t-1} \text { ahol: NOPLAT: Üzemi eredmény } \times\left(1-t_{\text {eff }}\right) \\
\text { IC: Befektetett eszközök + Forgóeszközök - Rövid lejáratú köt. }\end{array}$ \\
\hline DIVIDEND_RATIO: & Jóváhagyott osztalék, részesedés / Adózott eredmény \\
\hline KZ: & $\begin{array}{l}\text { A nem tőzsdei cégekre szóló Kaplan és Zingales (1997) index, } \\
\mathrm{KZ}=-1,002 \times \text { CF/ASSETS }+3,3139 \times \text { LEVERAGE }-39,368 \times \text { DIV } \\
-1,315 \times \text { CASH/ASSETS }\end{array}$ \\
\hline WW: & $\begin{array}{l}\text { Withed-Wu (2006) index: } \\
\text { WW =-0,091 × CF/ASSETS - 0,062 × DIVIDEND_PAYER + 0,021 × LEVERAGE } \\
\text {-0,044 × LOGASSET + 0,102 × IND_SALES_GROWTH - 0,035 × SALES_GROWTH } \\
\text { ahol IND_SALES_GROWTH iparági átlagos árbevétel-növekedés (kétszámjegyú } \\
\text { TEÁOR alapján), DIVIDEND_PAYER az osztalékot fizető cégek dummy változója }\end{array}$ \\
\hline CLEARY: & $\begin{array}{l}\text { Cleary (1999) index: } \\
\text { CLEARY = -0,119 × CURRENT - 1,904 × LEVERAGE + 0,001 × INTEREST_COV } \\
\text { + 1,456 × PROFIT_SALES + 2,035 × SALES_GROWTH - 0,048 × SLACK, } \\
\text { ahol a pénzügyi likviditási tartalékokat mérő mutató } \\
\text { SLACK = (Készpénz és készpénz-egyenértékesek + 0,5 × Készletek } \\
\text { + 0,7 } \times \text { (Vevők - Rövid lejáratú kötelezettségek) ) / Befektetett eszközök }\end{array}$ \\
\hline COST_SALES: & Anyag jellegű ráfordítások \\
\hline AP_COST_SALES: & Szállítók / Anyagjellegú ráfordítások \\
\hline
\end{tabular}


A 3. táblázatban listázzuk az általunk használt változók rövid nevét és kifejtésüket. Az adatbázisban a nemzetközi irodalomban gyakori (lásd például Petersen és Rajan 1997, Nilsen 2002, Cunningham 2005, vagy Bougheas, Mateut és Mizen 2007), hogy a forgási idő (AP/COST_SALES × 365) változó helyett a szállítótartozás nagyságát mérik az AP/Sales aránnyal, aminek során az árbevétel nagyságával normalizálnak. A nemzetközi összehasonlíthatóság érdekében ez utóbbi változó választása mellett döntöttünk. A szállítótartozásokat a mérlegek Kötelezettségek áruszállításból és szolgáltatásból (szállítók) sorainak segítségével mértük. A rövid lejáratú hitelek azonosításához a mérlegből a Rövid lejáratú kötelezettségek tételen belül szereplő Rövid lejáratú hitelek soron lévő adatokat használtuk (nem soroltuk ide a Rövid lejáratú kölcsönök tételt). A rövid lejáratú hitelek tétele tartalmazhatja az egy évnél hosszabb lejáratú hitelek egy éven belül esedékes törlesztéseit is, ennyiben a rövid lejárattal kapcsolatos megállapításainkat kritikusan kell kezelni. Bár a választott tétel nem szükségszerűen kizárólag a bankhiteleket tartalmazhatja, de funkciójában a rövid lejáratú, nem a szállítóktól származó rövid forrásokat gyǔjti össze, amely a szállítói finanszírozás alternatívájaként tekinthető.

A mutatók egy csoportja esetében (AP_SALES, AR_SALES, CASH_SALES, ST_LOANS_SALES, LT_LOANS_SALES, SALES_GROWTH, AP/COST_SALES) a felső 1 százalékon winzorizálást alkalmaztunk, míg más esetekben (EBIT_SALES, PROFIT_SALES, CAPEX_SALES, ROIC) alsó és felső 1 százalékon winzoráltunk. Speciálisabb változóknál, így a COVERAGE_RATIO (20 százalék; 70 százalék), INTEREST_COV (20 százalék; 70 százalék), SLACK (5 százalék; 90 százalék), ROE (8 százalék; 90 százalék) ettől eltérő szabályt alkalmaztunk.

Az adatbázisban a legfontosabb változók leíró statisztikáit a 4. táblázatba gyűjtöttük össze. Az A) panelben a teljes 2010-2015-ös periódus adatait vettük figyelembe, a B) részhez csak 2011-2015-öt, mert több számított arány esetében is a nevezőben a 2010-es érték szerepel. A mintában a szállítói állomány mediánja 16 millió Ft körül alakult, míg a vevőállomány 20,5 millió Ft volt. A vállalkozások több mint harmada rendelkezett rövid lejáratú bankhitelekkel, ennél kisebb arányban pedig hosszú távú hitelekkel. A mérlegfőösszeg mediánja a mintában 385 millió Ft-ot tett ki. A szállító-árbevétel arány mediánja 5 százalék volt, a vevő-árbevétel arány pedig 8,4 százalék körül alakult. 


\begin{tabular}{|c|c|c|c|c|c|c|c|c|}
\hline \multicolumn{9}{|l|}{$\begin{array}{l}\text { 4. táblázat } \\
\text { Összegző statisztikák }\end{array}$} \\
\hline \multicolumn{9}{|c|}{ Panel A: Föbb tételek } \\
\hline Ezer Forintban & $\mathbf{N}$ & Mean & St. Dev. & Min & Pctl(25) & Median & $\operatorname{Pctl}(75)$ & Max \\
\hline ACCOUNTS_PAYABLE & 71568 & 105172 & 228182 & 0 & 694 & 15916 & 98422 & 2138715 \\
\hline ACCOUNTS_RECEIVABLE & 71568 & 154412 & 404037 & 0 & 976 & 20588 & 139871 & 16552101 \\
\hline ST_LOANS & 71568 & 75464 & 390532 & 0 & 0 & 0 & 17542 & 15724355 \\
\hline LT_LOANS & 71568 & 26932 & 142189 & 0 & 0 & 0 & 0 & 2146469 \\
\hline ASSET & 71568 & 1254481 & 7441845 & 1 & 51983 & 385357 & 1172100 & 1240000000 \\
\hline SALES & 71568 & 1220289 & 2762188 & 101 & 35276 & 332765 & 1300015 & 111000000 \\
\hline
\end{tabular}

\begin{tabular}{l|c|c|c|c|c|c|c|c}
\hline \multicolumn{7}{c}{ Panel B: $A$ múködést jellemzö mutatók } \\
\hline Arányok & N & Mean & St. Dev. & Min & PctI(25) & Median & PctI(75) & Max \\
\hline AP_SALES & 57014 & 0,139 & 0,352 & 0,000 & 0,010 & 0,050 & 0,127 & 2,838 \\
\hline AR_SALES & 57014 & 0,154 & 0,258 & 0,000 & 0,016 & 0,084 & 0,182 & 1,805 \\
\hline EBIT_SALES & 57014 & $-0,053$ & 0,747 & $-5,643$ & 0,000 & 0,035 & 0,111 & 0,964 \\
\hline ST_LOANS_SALES & 57014 & 0,074 & 0,263 & 0,000 & 0,000 & 0,000 & 0,033 & 2,126 \\
\hline LT_LOANS_SALES & 57014 & 0,049 & 0,270 & 0,000 & 0,000 & 0,000 & 0,000 & 2,362 \\
\hline LEVERAGE & 57014 & 0,488 & 0,302 & 0,000 & 0,232 & 0,473 & 0,734 & 0,989 \\
\hline CURRENT & 57014 & 3,555 & 5,388 & 0,000 & 0,960 & 1,538 & 3,109 & 22,548 \\
\hline CASH_SALES & 57014 & 0,352 & 1,081 & 0,000 & 0,017 & 0,066 & 0,220 & 8,546 \\
\hline INTEREST_COV & 57014 & 4,753 & 12,281 & $-14,587$ & 0,007 & 1,865 & 21,187 & 22,445 \\
\hline CAPEX_SALES & 57014 & 0,074 & 0,408 & $-1,653$ & 0,000 & 0,012 & 0,058 & 2,777 \\
\hline SALES_GROWTH & 57014 & 0,186 & 0,958 & $-1,000$ & $-0,119$ & 0,028 & 0,200 & 7,063 \\
\hline ROE & 57014 & 0,155 & 0,521 & $-0,907$ & 0,002 & 0,085 & 0,316 & 1,201 \\
\hline ROIC & 57014 & 0,247 & 1,302 & $-4,487$ & $-0,000$ & 0,076 & 0,256 & 8,685 \\
\hline
\end{tabular}

Az empirikus vállalati pénzügyi irodalomban a pénzügyi korlátosságot mérő változókat Farre-Mensa és Ljungqvist (2014), valamint Elsas és Klepsch (2016) hasonlítja össze egymással. A szerzők által használt változók közül a rövid lejáratú bankhitelhez jutás korlátosságát a három legelterjedtebb változóval mérjük: a nem tőzsdei cégekre vonatkozó Kaplan-Zingales-index, Whited-Wu-index, valamint Cleary-index segítségével. A pénzügyi korlátosságot Farre-Mensa és Ljungqvist (2014) dolgozatában összefoglalt statisztikai eljárások alapján definiáljuk. A Kaplan-Zingales-, a Whited-Wu-indexek, valamint a Cleary-index mínusz egyszeresét nagyság szerint sorba állítják, majd a felső 30 percentilisbe tartozó megfigyeléseket nem korlátosnak, az alsó 30 percentilisbe tartozókat pedig korlátosnak definiálják. A középső 40 százalékba tartozó elemek egyik esetbe sem tartoznak, ezt egyfajta szürke zónának tekintik. Ezt az eljárást és a szétválogatást a teljes mintára és teljes vállalat-év megfigyelésre alkalmaztuk. Ez azt jelenti, hogy bizonyos cégek besorolása az évek során változhat, 
de a változás nem jellemző a mintában. Az 5. táblázatban összehasonlítjuk a három besorolást. A Kaplan-Zingales-eljárás a nagyvállalatok kivételével vállalatmérettől nagyjából függetlenül kategorizálja a cégeket. Kivétel a nagyvállalatoknál, ahol a kapacitáskorláton lévő cégek aránya kb. 50 százalékos, ami a KZ-eljárás alacsony megbízhatóságát jelzi. (Kaplan és Zingales (1997) egy viszonylag homogén mintán önbevalláson alapuló kategóriákon becsülte meg az indexet az eredeti cikkben.) A Cleary-eljárásra közepesen, míg a Whited-Wu-eljárásra nagymértékben jellemző, hogy a kisebb cégek, főleg a mikrovállalkozások kerültek a hitelkapacitás-korlátos besorolásba. Megjegyezzük, az egyes eljárásokat a nemzetközi szakirodalom sem tekinti egymás tökéletes alternativáinak, ezért használunk több besorolást is az elemzésekhez.

\begin{tabular}{|c|c|c|c|c|c|c|c|c|c|c|c|c|}
\hline \multicolumn{13}{|c|}{$\begin{array}{l}\text { 5. táblázat } \\
\text { A hitelkapacitás-korlátossági mutatók besorolása }\end{array}$} \\
\hline \multirow[b]{2}{*}{ Méret } & \multirow[b]{2}{*}{ Év } & \multirow{2}{*}{$\begin{array}{l}\text { Válla- } \\
\text { latok } \\
\text { száma }\end{array}$} & \multicolumn{10}{|c|}{ Hitelkapacitás-korlátos vállalatok száma az egyes besorolások szerint } \\
\hline & & & KZ & CLEARY & WW & $\begin{array}{c}\text { KZ \& } \\
\text { CLEARY }\end{array}$ & $\begin{array}{l}\text { KZ \& } \\
\text { WW }\end{array}$ & $\begin{array}{l}\text { CLEARY } \\
\& W W\end{array}$ & $\begin{array}{l}\text { Mind- } \\
\text { három }\end{array}$ & $\begin{array}{c}\text { KZ/ } \\
\text { Összes }\end{array}$ & $\begin{array}{c}\text { CLEARY/ } \\
\text { Összes }\end{array}$ & $\begin{array}{c}\text { WW/ } \\
\text { Összes }\end{array}$ \\
\hline Nagy & 2011 & 68 & 39 & 5 & 0 & 3 & 0 & 0 & 0 & $57 \%$ & $7 \%$ & $0 \%$ \\
\hline Nagy & 2012 & 68 & 35 & 5 & 1 & 2 & 1 & 1 & 1 & $51 \%$ & $7 \%$ & $1 \%$ \\
\hline Nagy & 2013 & 67 & 30 & 8 & 1 & 3 & 1 & 1 & 1 & $45 \%$ & $12 \%$ & $1 \%$ \\
\hline Nagy & 2014 & 67 & 34 & 6 & 0 & 2 & 0 & 0 & 0 & $51 \%$ & $9 \%$ & $0 \%$ \\
\hline Nagy & 2015 & 34 & 14 & 6 & 1 & 1 & 0 & 1 & 0 & $41 \%$ & $18 \%$ & $3 \%$ \\
\hline Közép & 2011 & 1269 & 434 & 143 & 5 & 63 & 5 & 0 & 0 & $34 \%$ & $11 \%$ & $0 \%$ \\
\hline Közép & 2012 & 1310 & 431 & 181 & 11 & 80 & 9 & 7 & 5 & $33 \%$ & $14 \%$ & $1 \%$ \\
\hline Közép & 2013 & 1298 & 416 & 195 & 15 & 79 & 11 & 12 & 9 & $32 \%$ & $15 \%$ & $1 \%$ \\
\hline Közép & 2014 & 1254 & 365 & 192 & 18 & 64 & 13 & 12 & 9 & $29 \%$ & $15 \%$ & $1 \%$ \\
\hline Közép & 2015 & 734 & 184 & 128 & 9 & 43 & 6 & 9 & 6 & $25 \%$ & $17 \%$ & $1 \%$ \\
\hline Kis & 2011 & 3966 & 1177 & 698 & 110 & 317 & 72 & 50 & 32 & $30 \%$ & $18 \%$ & $3 \%$ \\
\hline Kis & 2012 & 4201 & 1233 & 867 & 121 & 353 & 86 & 74 & 49 & $29 \%$ & $21 \%$ & $3 \%$ \\
\hline Kis & 2013 & 4168 & 1150 & 864 & 134 & 369 & 92 & 103 & 68 & $28 \%$ & $21 \%$ & $3 \%$ \\
\hline Kis & 2014 & 3967 & 1041 & 818 & 131 & 324 & 86 & 90 & 57 & $26 \%$ & $21 \%$ & $3 \%$ \\
\hline Kis & 2015 & 2333 & 498 & 494 & 72 & 160 & 47 & 57 & 35 & $21 \%$ & $21 \%$ & $3 \%$ \\
\hline Mikro & 2011 & 8282 & 2497 & 2791 & 4110 & 1085 & 1538 & 1827 & 656 & $30 \%$ & $34 \%$ & $50 \%$ \\
\hline Mikro & 2012 & 8581 & 2735 & 3273 & 4392 & 1200 & 1684 & 2164 & 799 & $32 \%$ & $38 \%$ & $51 \%$ \\
\hline Mikro & 2013 & 7288 & 2179 & 2706 & 3448 & 957 & 1264 & 1659 & 576 & $30 \%$ & $37 \%$ & $47 \%$ \\
\hline Mikro & 2014 & 6266 & 1758 & 2311 & 2873 & 773 & 976 & 1390 & 446 & $28 \%$ & $37 \%$ & $46 \%$ \\
\hline Mikro & 2015 & 3618 & 854 & 1413 & 1652 & 388 & 477 & 888 & 240 & $24 \%$ & $39 \%$ & $46 \%$ \\
\hline
\end{tabular}


Az első vizsgálatban a szállítótartozások és a rövid, valamint a hosszú lejáratú bankhitelek, továbbá a vevők általános kapcsolatát vizsgáljuk, ha a banki finanszírozáshoz jutás korlátozott. E célból az alábbi regressziós egyenleteket becsüljük meg:

$$
\begin{aligned}
& \text { AP/SALES }=\text { ST_LOANS } / \text { SALES }+ \text { LT_LOANS } / \text { SALES }+ \text { AR/SALES + } \\
& \text { + controls + Firm FE + Year FE } \\
& \text { AP/SALES }=\text { ST_LOANS } / \text { SALES }+ \text { LT_LOANS } / \text { SALES + AR/SALES + } \\
& \text { + FINC_Dummy + FINC_Dummy } \times \text { ST_LOANS/SALES + } \\
& \text { + controls + Firm FE + Year FE } \\
& \text { AP/SALES }=\text { ST_LOANS } / \text { SALES }+ \text { LT_LOANS } / \text { SALES }+ \text { AR/SALES + } \\
& \text { + FINC_Dummy + FINC_Dummy } \times \text { LT_LOANS/SALES + } \\
& + \text { controls + Firm FE + Year FE } \\
& \text { AP/SALES }=\text { ST_LOANS/SALES + LT_LOANS } / \text { SALES }+ \text { AR/SALES + } \\
& \text { + FINC_Dummy + FINC_Dummy } \times \text { AR/SALES + } \\
& + \text { controls + Firm FE + Year FE }
\end{aligned}
$$

Ahol FINC_Dummy (financially constrained) a banki finanszírozási kapacitásait kimerítő vállalatok indikátorváltozója. A Firm FE a vállalati fix hatásokat, a Year FE az időbeli fix hatásokat jelöli. A kontrollváltozók között az összes olyan változó szerepel, amely az egyedi vállalati hatásokon túl az egyedi múködési és növekedési jellemzőket jól ragadja meg: vállalatméret (log(ASSET)), operatív árrés (EBIT_SALES), jövedelmezőségi mutató (ROE), kamatfedezeti hányados (INTEREST_COV), tôkeáttételi mutató (LEVERAGE) késleltetettje, likviditási ráta (CURRENT) késleltetettje, pénzállomány-arány (CASH_SALES) késleltetettje, a beruházási kiadások - árbevétel arány (CAPEX_SALES) késleltetettje, osztalékfizetési ráta (DIVIDEND_RATIO), árbevétel növekedési üteme (SALES_GROWTH).

Az 1A egyenlet építésére vonatkozó első ötletet Cunningham (2005) adta, de jelentősen eltérünk attól: más alap- és kontrollváltozókat használunk. Az 1B egyenlet a szállítótartozások és a hosszú hitelek kapcsolatát vizsgálja, hogy válaszolni tudjunk arra a kérdésre, hogy vajon a cégek növelik-e hosszú távú hiteleiket a kereskedelmi hitel növelésével. Az $1 \mathrm{C}$ egyenlet nem az elméleti modellből, hanem gyakorlati megfontolásokból származik. Itt arra vagyunk kíváncsiak, hogy ott, ahol nagyobb a vevő/árbevétel arány, átterhelik-e a cégek a finanszírozást a szállítóikra.

A második vizsgálatban a szállítói finanszírozáshoz való hozzáférést is vizsgáljuk. Burkart és Ellingsen (2004) az elméleti modellben a vállalat vagyoni helyzetével választja el, hogy melyik finanszírozási lehetőségben éri el a vállalat a korlátját. Nagy vagyon esetén kevésbé támaszkodnak külső finanszírozásra, egyik korlát sem 
él. Közepes vagyon esetén a banki hitelkapacitásait kihasználják, de a banki szállítótartozásban rejlő kapacitást nem. Kis vagyon esetén sok külső forrást vonnak be, így mindkettő formában korlátokkal szembesülnek. Mivel vállalati vagyont nehéz megfigyelni, így a vagyont a vállalatok átlagos jövedelmezőségével (EBIT/ASSET, vagyis üzemi eredmény a mérlegfőösszeg arányában) proxyzzuk: e mögött az áll, hogy egy jól jövedelmező cég képes belső forrásokat felhasználni. Az adatbázist három részmintára bontjuk aszerint, hogy a cégek átlagos EBIT/ASSET mutatóik szerint alacsony (<0 százalék), közepes ( 0 százalék-14 százalék közötti), vagy magas (>14 százalék) jövedelmezőségűek-e üzleti értelemben. A részmintákon a korábbi modellspecifikációk közül az (1A)-t futtatjuk a háromféle korlátossági mutatóval, ahol csak a bankhitelben korlátos indikátorváltozót használjuk, a szürke zóna és a bankhitelben nem korlátos cégeket együttesen tekintve kontrollcsoportnak.

A harmadik vizsgálat során arra vagyunk kíváncsiak, hogy a vállalatméret mennyire befolyásolja a szállítói finanszírozás és a rövid lejáratú bankhitelek kapcsolatát. Nilsen (2002) az amerikai vállalatok esetében a vállalatméretet találta a hozzáférést jól megragadó tényezőnek, bár vizsgálatait nem mikroszintű paneladatokon végezte. A korábbi (1) és (1A) egyenleteinket becsüljük újra négy részmintára: a nagy-, a közepes, a kis- és a mikrovállalatok csoportjára, ahol mi a magyar vállatokra alkalmazott általános méretdefiníciók közül az árbevételre vonatkozó kritériumokat használtuk (50 millió euró, 10 millió euró, 2 millió eurós küszöbökkel 300 Ft/eurós átváltási árfolyammal). Egy szállító-vevő viszonyban a nagyobb méret plusz alkuerőt jelenthet a cégnek a szállítóval szemben, így a nagyobb cégek ritkábban szembesülnek kemény szállítói korlátokkal. Kíváncsiak vagyunk arra, hogy a vállalatméret mennyiben ragadja meg ezt az összefüggést, de már önmagában a különböző méretű cégek közötti különbségek feltárása is érdekes tanulságokat hozhat. Itt szintén a korábban megadott $(1 \mathrm{~A})$ egyenletet becsüljük a három korlátossági dummy változó mellett.

A negyedik elemzés a szállítói finanszírozás üzleti ciklusokra vonatkozó érzékenységét számszerűsíti. Részmintánként (méret alapján bontva) az alábbi regressziós egyenlettel közvetlenül a szállítói forgási időt becsüljük:

$$
\begin{gathered}
\text { AP/COST_SALES } \times 365=\text { AR/SALES } \times 365+\text { ST_LOANS/SALES }+ \text { LT_LOANS/SALES + } \\
+ \text { FINC_Dummy + FINU_Dummy }+\sum_{t=1}^{4} \text { YEAR_Dummy }++ \\
+\sum_{t=1}^{4} Y E A R \_D u m m y_{t} \times \text { FINC_Dummy }+ \\
+\sum_{t=1}^{4} Y E A R \_ \text {Dummy }+ \\
\times \text { FINU_Dummy }+ \\
+ \text { controls }+ \text { Firm FE }
\end{gathered}
$$


Ahol a FINC és FINU (financially uncontrained) dummy változók nem fedik le a teljes mintát, hiszen annak 40 százaléka a szürke zónába esik. A becslésből az időfix hatásokra, valamint a velük való interakciókra vagyunk kíváncsiak. Vagyis arra, hogy minden más változatlansága mellett csupán a konjunkturális hatások miatt hogyan alakul a különböző finanszírozási hozzáféréssel rendelkező vállalati szegmensek szállítótartozásainak forgási ideje, ha bankhitelkapacitásait kihasználja. Ebben az esetben az eredményváltozót 365 nappal megszorozzuk, hogy az eredményt napokban értelmezhessük. A COST_SALES változó esetén figyelembe kellett vennünk azt is, hogy nem minden vállalat egyazon logika mentén számolja az értékesítéshez kapcsolható kiadások eredményhatásait. A vállalatok egy része összköltséges, míg másik része forgalmi szemléletű eredménykimutatást készített. Az első esetben az anyagköltség és az igénybe vett szolgáltatások összege, míg a második esetben az eladott áruk beszerzési értéke, valamint az eladott szolgáltatások értékének összege jelentette azt az alapot, amely - nem azonnali kiegyenlítés esetén - szállítótartozássá alakulhat. Mindkét típusú adatközlésben megtalálható volt az anyagjellegű ráfordítások tétel, amely nagyon kevés (1 százaléknál kisebb) esetben tért el, akkor is csak kismértékben a kétféle módon számított összegtől.

A regressziókat fixed effects within panel módszerrel becsültük meg, ahol az vállalati (Firm) egyedi fix hatásokat within becslési technikával, az időbeli, éves (Year) hatást pedig dummy változók alkalmazásával szűrtük ki. A panelek kiegyensúlyozatlan panelek, mert a megfigyelt cégek öt évnél rövidebb ideig is benne lehettek a mintában. A Breusch-Pagan-féle, valamint a Honda-féle LM-próba sem fogadta el azt a nullhipotézist, hogy nem szignifikáns az időhatás a regressziókban. Az egyedi (vállalati) hatások is jellemzően szignifikánsak voltak. A becslésekre futtatott Hausmann-tesztek pedig a fix hatás használatát támogatták a véletlen hatással szemben. A becsült modellek hibatagjai heteroszkedaszticitásról árulkodtak, viszont a hibatagokban a négy megfigyelési évre nem volt jelentős autokorreláció, így White-féle heteroszkedaszticitás-konzisztens standard hibákkal számoltunk a statisztikai tesztekben.

\section{Eredmények}

Vizsgálatunk első kérdésének becslési eredményeit (1, 1A, 1B és 1C egyenletek) a 6 . táblázat foglalja össze, az első oszlop az alapegyenlet együtthatóit tartalmazza, majd a három egyenletet a Kaplan-Zingales-, Whited-Wu- és Cleary-alapú besorolással készült hitelkorlátossági mutatókat használva. Az eredményváltozó a szállítótartozás mértéke az árbevétel arányában, azonban ezt 100-zal megszorozva szerepeltetjük az együtthatók olvashatósága céljából. 


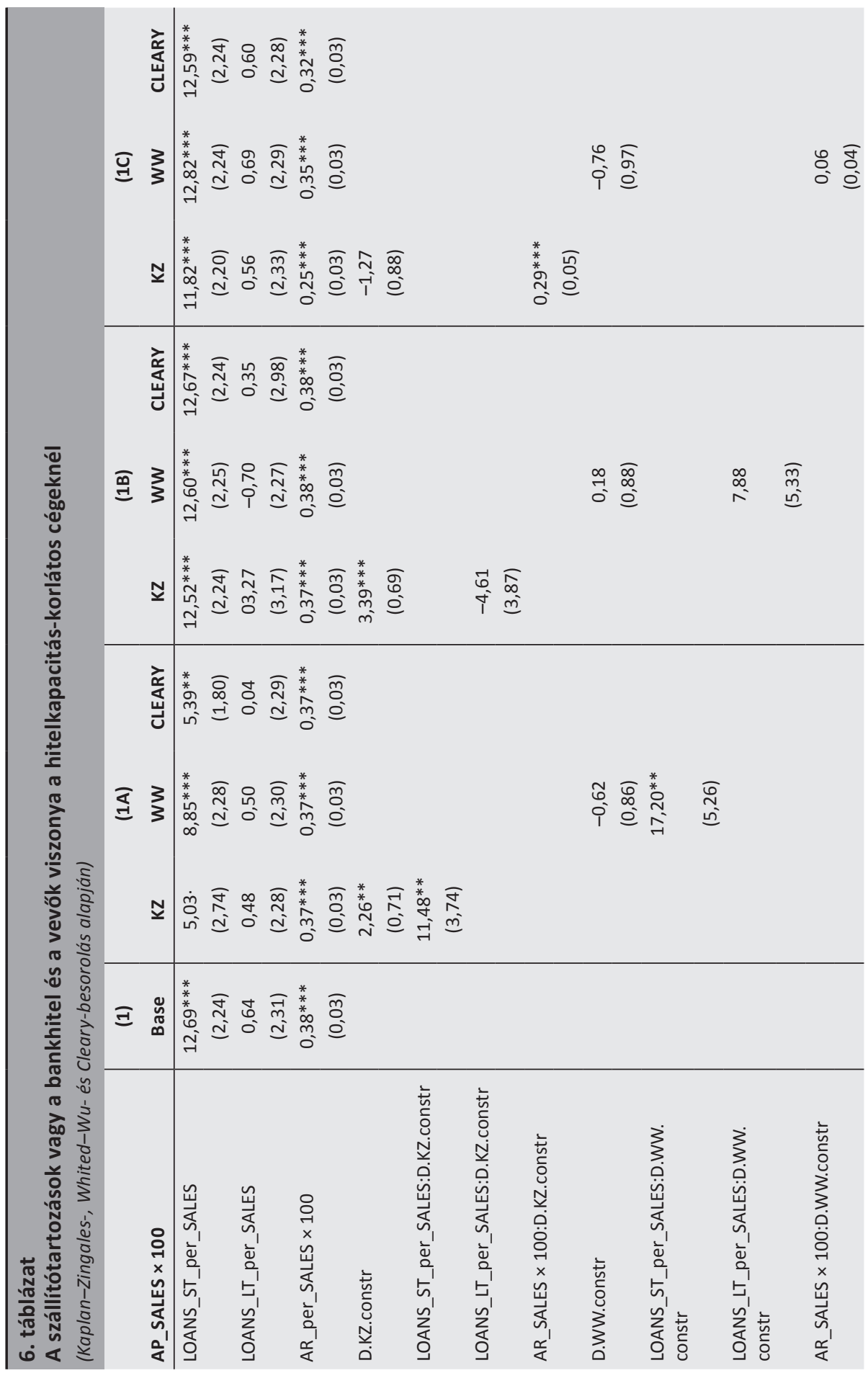




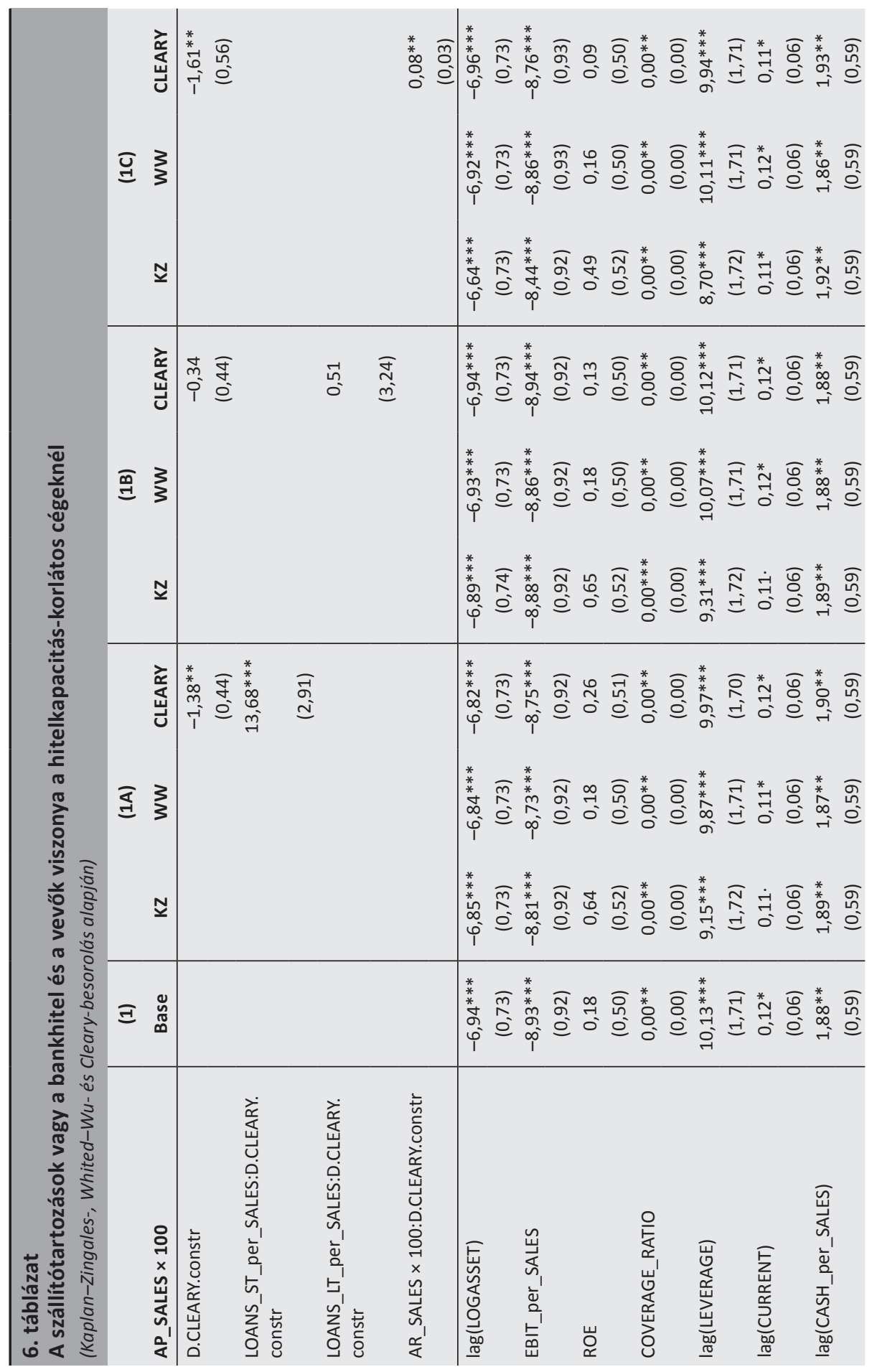




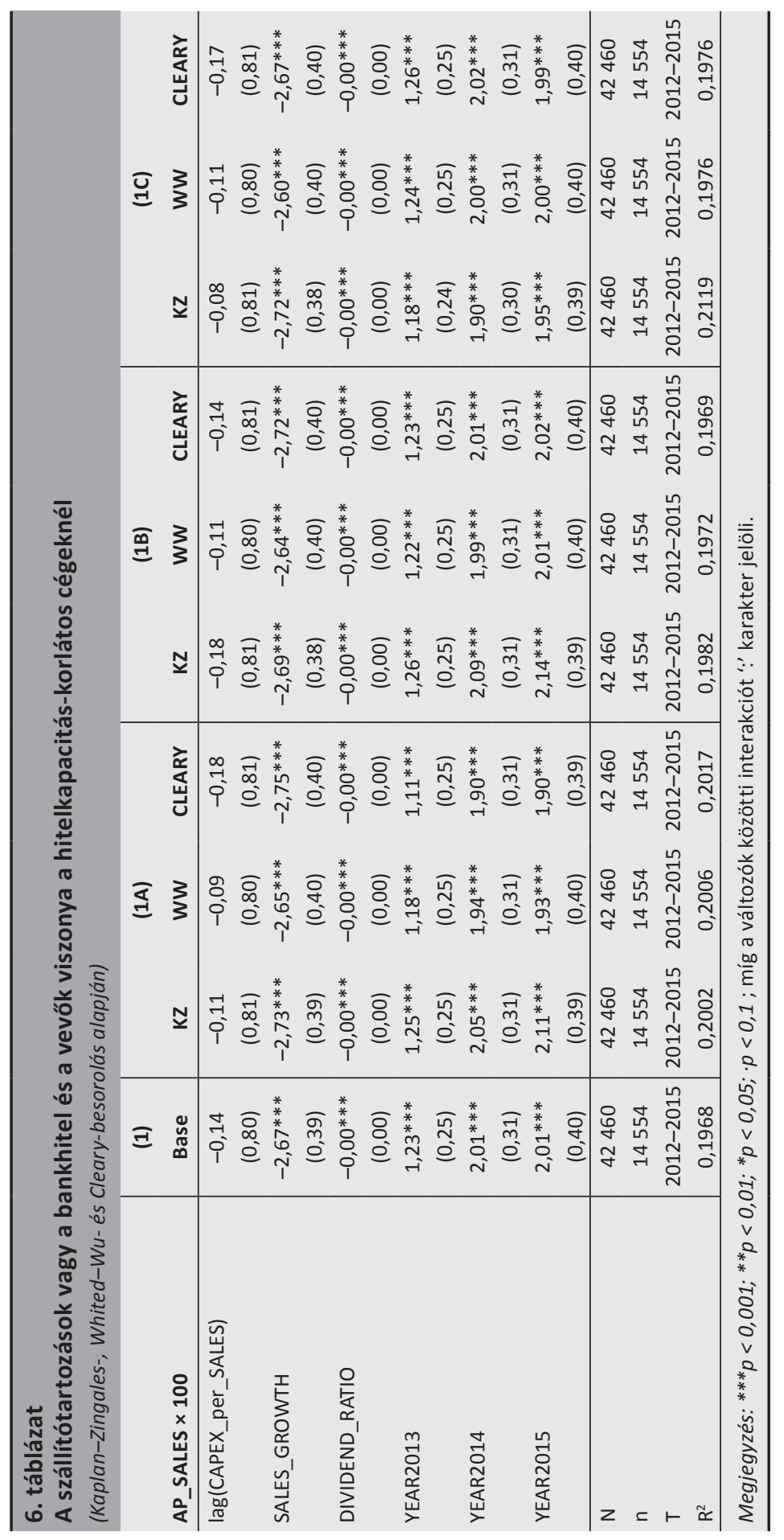


A táblázatot tekintve megállapíthatjuk, hogy a rövid távú bankhitelek jelenléte mindegyik becslés szerint növelte a szállítótartozások szintjét, erre utalnak a szignifikánsan pozitív ST_LOAN_SALES együtthatók. A within-becslés sajátosságából fakadóan az R-négyzetek értékei alacsonyak, de a változók összességében minden regressziós egyenlet esetében 1 százalékos küszöb mellett szignifikánsan magyarázzák a szállítótartozás arányát.

Az alapegyenlet becslésében azon cégeknél, ahol 10 százalékponttal (0,1-del) magasabb a rövid hitel versus árbevétel arány, átlagosan 1,269 százalékponttal magasabb a szállítótartozások aránya is. Mindez alapvetően arra utal, hogy ha Burkart és Ellingsen elméleti modelljét helyesnek gondoljuk, és ezt a fajta kiegészítő kapcsolatot az alacsony vagyonú szállítókban és bankhitelben is korlátos cégek esetén figyeljük meg, akkor a magyar cégek zöme a szerzők elmélete szerint bankhitel-kapacitásaik korlátján áll. Ez azt is jelentheti, hogy a bevezetett hitelkorlátossági mutatók inkább a kapacitáskorlátosság mértékét, nem pedig annak tényét ragadják meg.

A kontrollváltozóknál kapott együtthatókat is érdemes röviden áttekinteni. Azt találtuk, hogy a nagyobb cégek, valamint a nagyobb profitréssel dolgozó cégek átlagosan kisebb szállító-árbevétel aránnyal rendelkeznek. A jövedelmezőséget mérő ROE-mutató nem magyarázta szignifikánsan a szállítótartozások nagyságát, az osztalékfizetési ráta együtthatója pedig nulla nagyságú hatást mutatott. A nagyobb mértékben eladósodott társaságokra azt találtuk, hogy a következő évben nagyobb szállítótartozással rendelkeznek. A magasabb pénzeszközhányaddal rendelkezőknél nagyobb, a magasabb növekedési ütemet felmutató vállalkozásoknál pedig alacsonyabb szállító-árbevétel hányadost figyeltünk meg. Mindezek nem mondanak ellent az általános üzleti intuícióknak.

A pénzügyi korlátokat jelző mutatók nem hoztak minden esetben konzisztens eredményt. Ez az előbbi érvelésen túl a mutatók készítésének logikai különbségeiből adódhat, valamint abból, hogy a besoroláshoz alkalmazott indexeket amerikai adatokon készítették el, és a cégek múködési különbségei is ronthatják az alkalmazás megbízhatóságát. Így csak azokat a becslési eredményeket tekintjük robusztusnak, ahol mindhárom mutató hasonló eredményt adott. Megjegyezzük, hogy az eredmények értelmezésekor azokra a cégekre hivatkozunk korlátosként, ahol a bankhitel-dummy értéke egy, és nem korlátosként azokra, ahol ez az érték nulla (a szürke zóna és a felső 30 százalékba eső nem korlátosnak jelölt cégek együtt).

Az 1A egyenletek vizsgálatakor a rövid lejáratú hitel és a szállítótartozás kapcsolatára alapvetően kiegészítő viszonyt találtunk. A korlátossági dummy mutatók önmagukban többnyire inszignifikáns vagy inkonzisztens eredményt hoztak, de az interakciók szignifikánsak voltak és az együttes hatások (átlagos rövid lejáratú hitel állománya mellett) is a kiegészítő jellegre utalnak. 
Az 1B egyenletek esetében a hosszú lejáratú hitel és a szállítótartozás között nem találtunk összefüggést: nincs arra evidencia a teljes mintára becsülve, hogy a pótlólagos hosszú távú hitel felvétele és a szállítótartozások használata között van kapcsolat.

Az 1 C egyenletek becslései azt mutatják, hogy a nem bankkorlátos cégeknél, amenynyiben adott évben nő a vevőállomány, a szállítói finanszírozás aránya is nagyobb. A teljes mintán a bankhitelkorlátos cégeknél az együttes hatások inszignifikánsak és ellent is mondanak egymásnak. Ez arra utal, hogy a cégek áthárítási képessége iparágaktól, mérettől és más további tényezőktől függhetnek. 


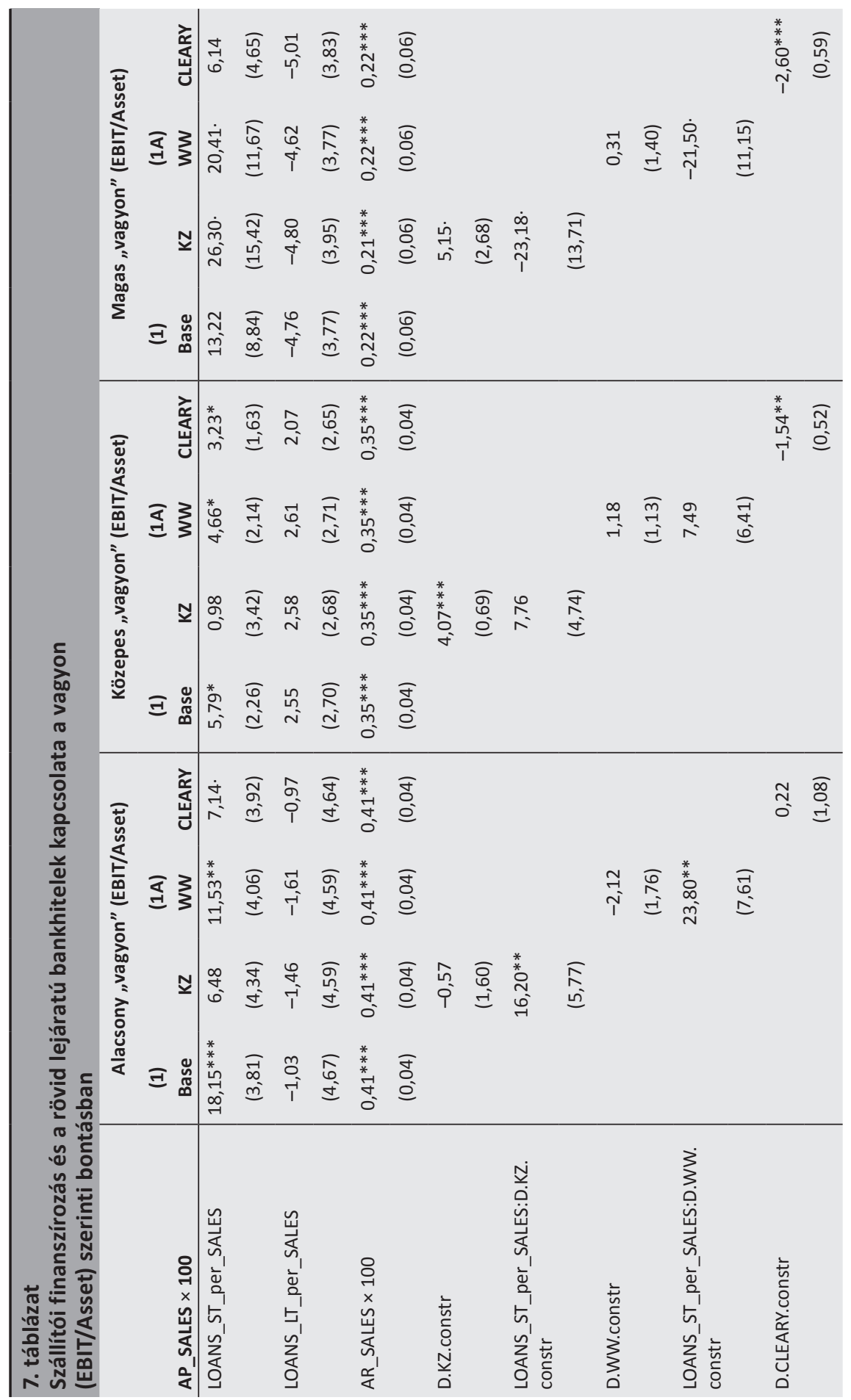




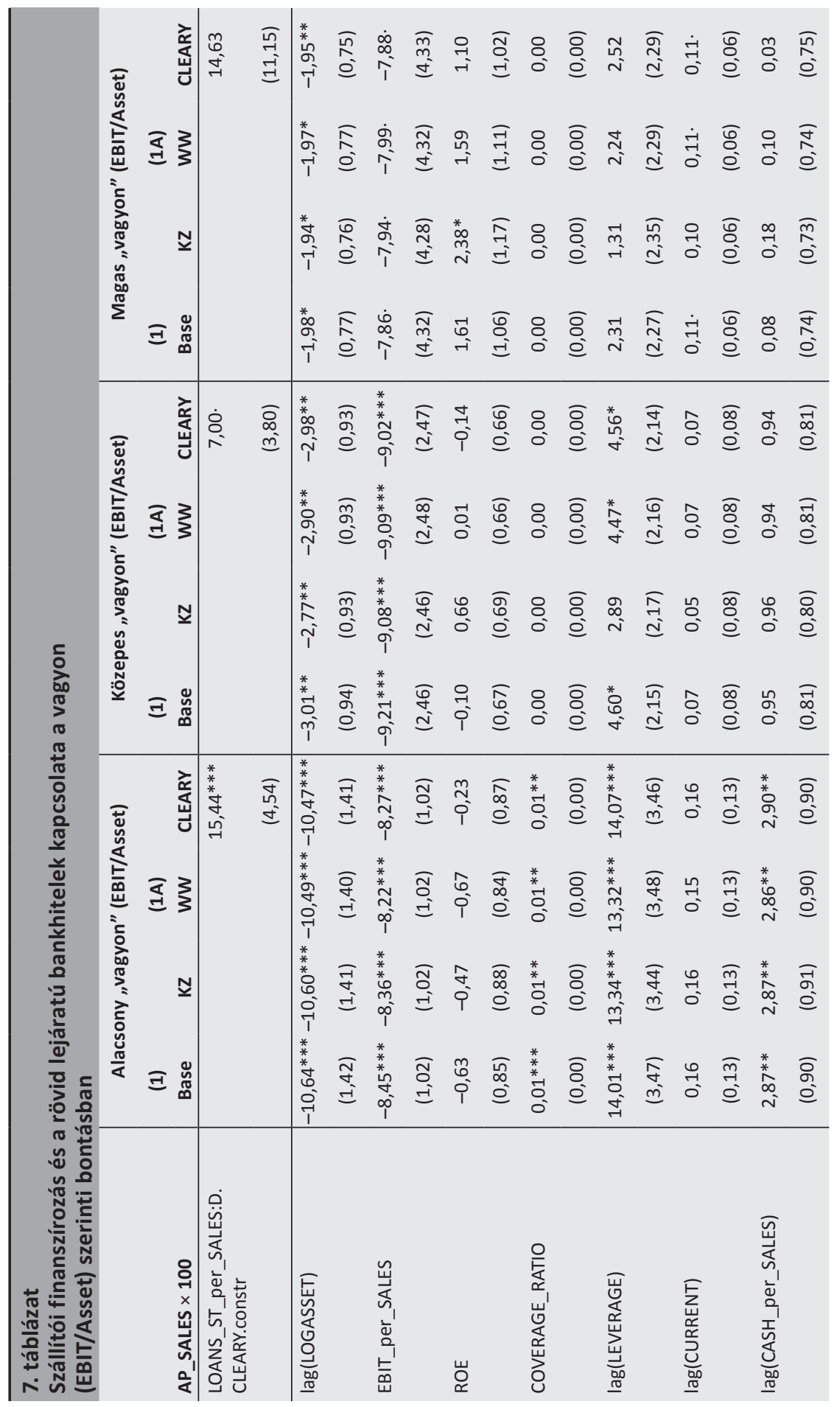




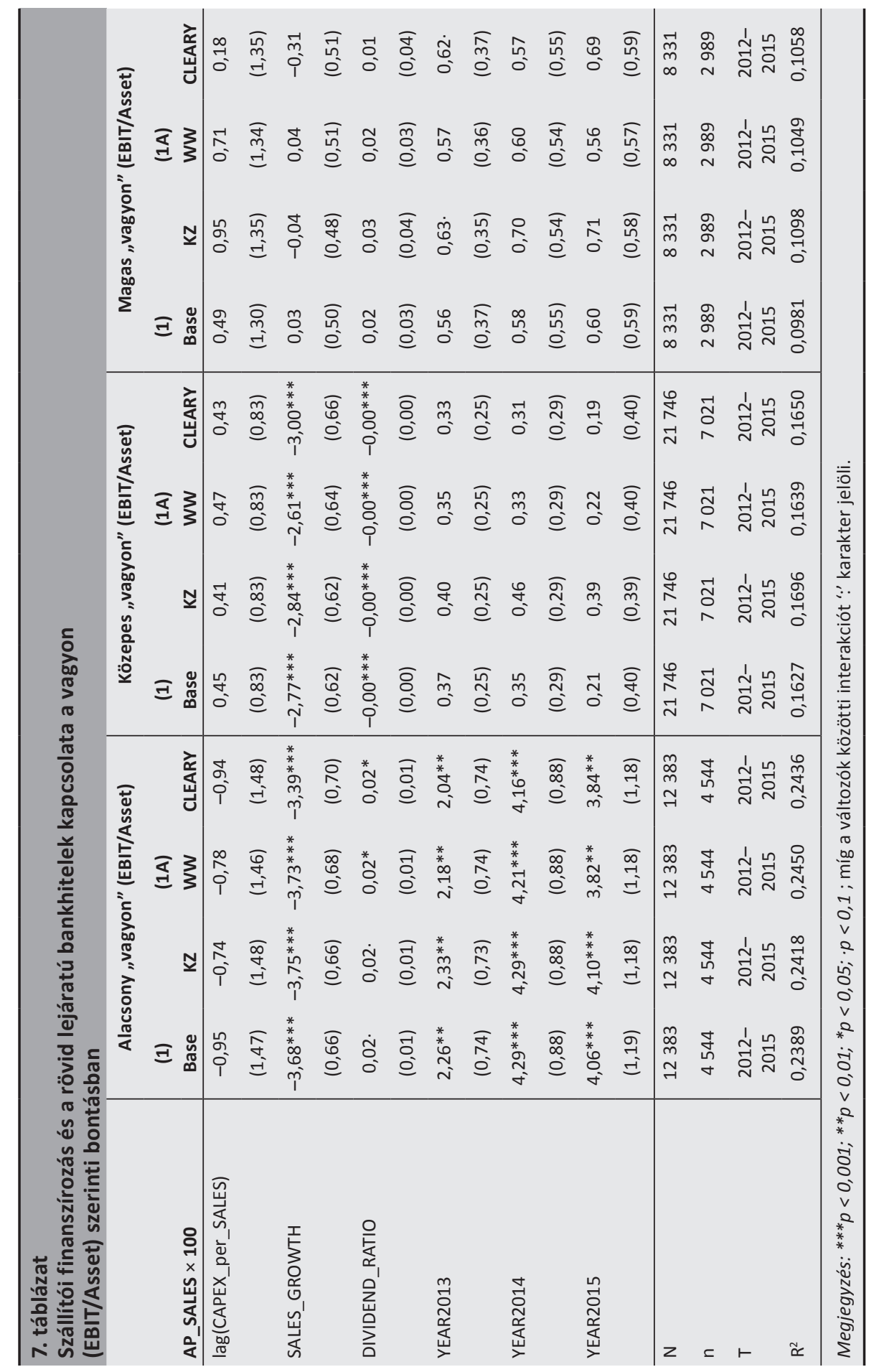


A második vizsgálat eredményeit a 7. táblázat foglalja össze. Az (1)-es és az (1A) egyenleteket becsültük három részmintára. Azon cégek mintájára, amelyeknek a) az átlagos EBIT/ASSET mutatójuk negatív volt (a minta alsó 26,6 százalékában vannak), b) ez az érték 0 és 14 százalék között volt, c) a 14 százalékot meghaladta (a minta felső 18,7 százalékában vannak). A küszöbértékek megválasztásában az játszott szerepet, hogy az átlagosan negatív teljesítményt felmutatókra illik a Burkart-Ellingsen-féle alacsony vagyon leírása, míg az átlagosan 14 százalékos küszöb mögött az szólt, hogy e fölötti jövedelmezőségnél az üzleti gyakorlatban általában már képesek belső forrást képezni, és a részminta elemszáma sem túl kicsi.

Az empirikus eredmények csak részben támasztják alá Burkart és Ellingsen modelljének állításait. Az első részmintában meg tudjuk erősíteni a prediktált kiegészítő hatást. Itt a kereskedelmihitel-korlátok és a bankhitelkorlátok egyszerre élnek az elmélet szerint, ezért nem lenne értelme megbontani az elemzést a KZ-, WW- és Cleary-alapú mutatókkal. Ettől függetlenül ezek a más elméletek alapján konstruált mutatók még ebben a tartományban is besorolnak cégeket korlátosnak és nem korlátosnak is. Ilyenkor úgy értelmezzük ezeket a mutatókat, hogy minden szereplő nehezen kaphat bankhitelt az alacsony jövedelmezőség miatt, és amelyeket az indexek is megjelölnek, ott valóban éles a kapacitáskorlát. Ekkor ebben a részmintában a rövid lejáratú hitelek és a szállítók között kiegészítő viszonyt találunk: ha nő a hitelek aránya, nő a szállítótartozás is, de csak az erősen korlátos cégekre robusztus az eredmény, ahol az együttes hatásba az interakciókat is belevesszük. A második részminta alig szignifikáns kiegészítő kapcsolatot mutat az (1)-es egyenletben. Ilyen esetben az elméleti modell predikciója a korlátos cégekre a helyettesítő viszony lenne, de ezt nem találtuk meg. Elképzelhetőnek tartjuk, hogy ez még Burkart és Ellingsen elméletében az alacsony vagyon kategóriába tartozik, ezért kapunk kiegészítő jelleget. A harmadik, nagy jövedelmezőséggel rendelkező cégek részmintájában 5 százalékos szignifikanciaszinten nem találtunk kapcsolatot, itt az elmélet szerint sincs kapcsolat. Ha elfogadjuk, hogy túl engedékenyek voltunk a vagyonos küszöb megválasztásánál, akkor a nincs hatás jelentheti azt, hogy ebben a részmintában helyettesítő és kiegészítő jelleg mellett múködő cégek egyaránt vannak. Összevetve Cunningham (2005) kanadai adatokon végzett hasonló célú kutatásával, Cunninghamnak nem sikerült a harmadik kategóriát beazonosítani, viszont a kiegészítő hatást az első, majd a helyettesítő hatást a második kategóriában igen. 


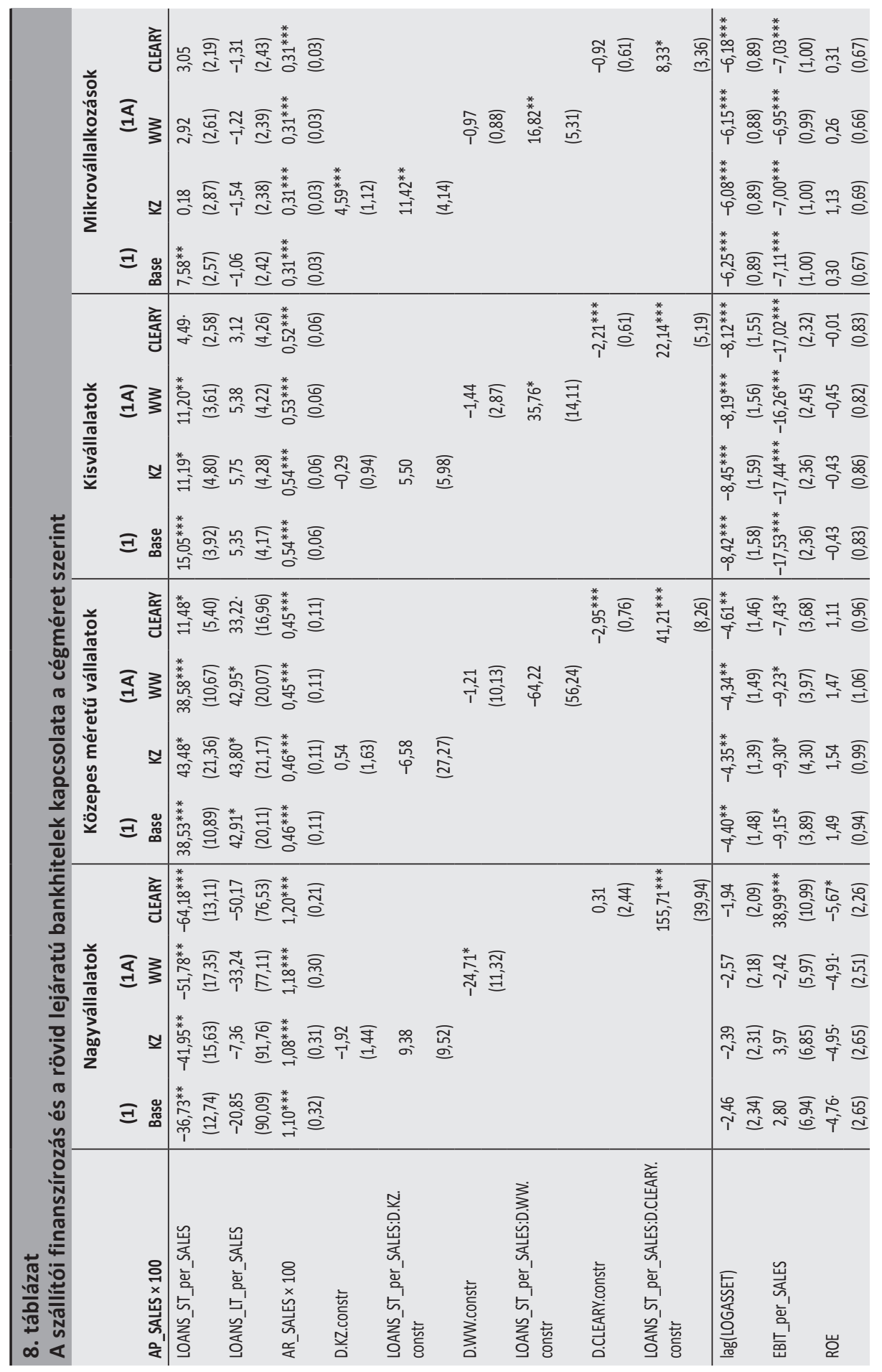




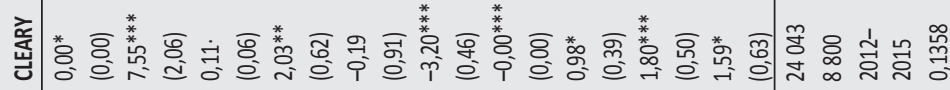

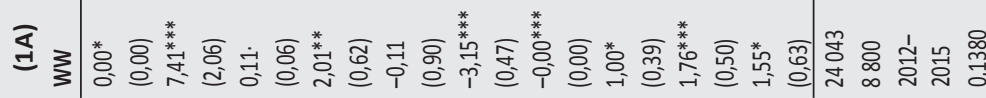

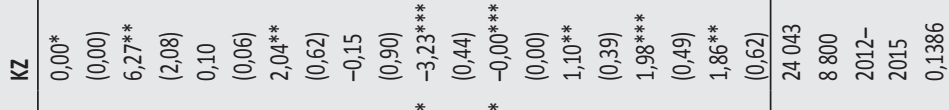

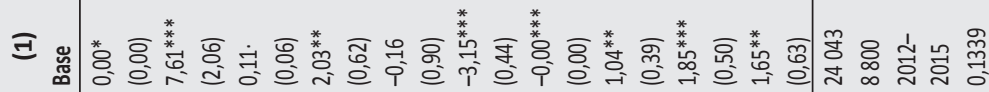

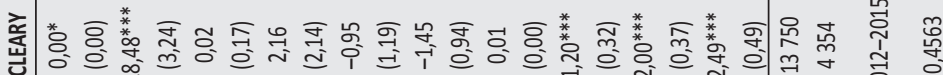

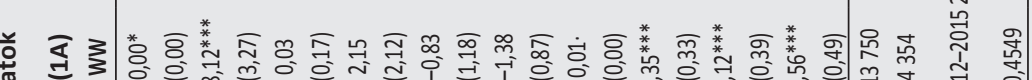

类

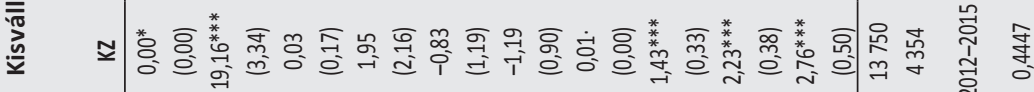

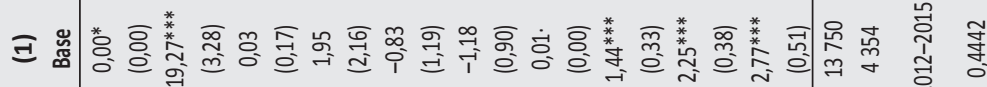

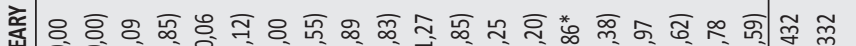

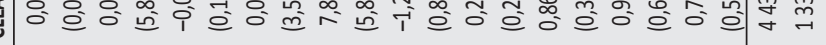

๔

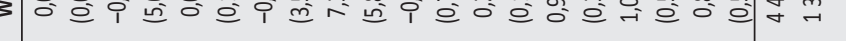

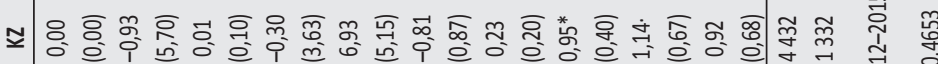

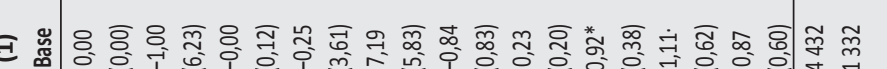

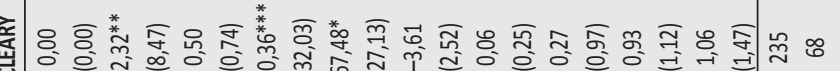

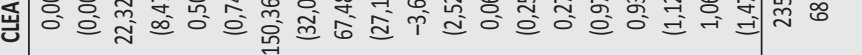

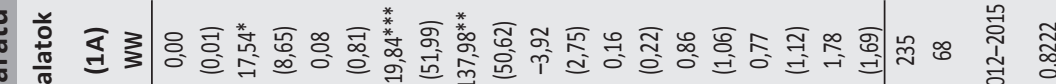

* * *

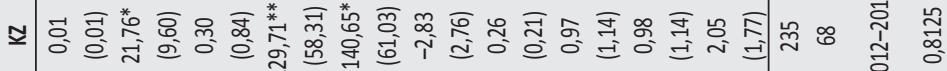

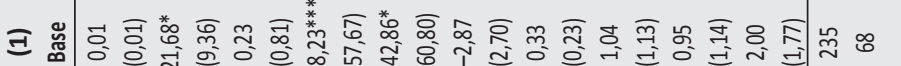

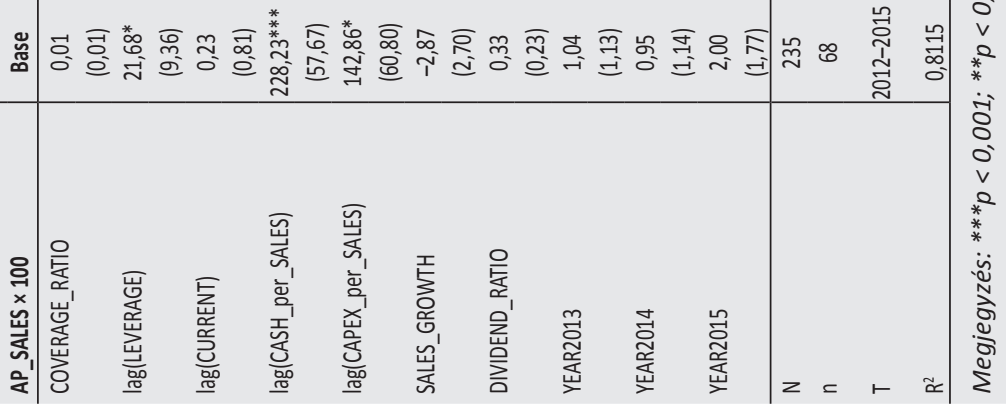


A helyettesítési hatás szempontjából érdekes jegyeket mutat a vállalatméret szerinti részmintákon végzett vizsgálat, amelynek eredményeit a 8. táblázatban közöljük. A nagyvállalati részmintában a rövid lejáratú hitelek becsült együtthatója minden esetben negatív. Ez arra utal, hogy helyettesítési viszonyt találunk a nagyvállalatoknál (függetlenül attól, hogy banki kapacitásaikat elérték-e már a három index szerint). A Whited-Wu-interakció becslését nem készítette el a modell (vélhetően azért, mert csak évente nulla, illetve egy céget jelöl ez a mutató korlátosnak), a másik két mutató pedig inkonzisztensnek mutatkozott. Ebben az esetben inkább amellett érvelünk, hogy a nagyvállalatok és a bankok viszonya eltér a többi esettől, és méretüknél fogva sokszor egyszerúbb a szállítói finanszírozást igénybe venniük, mint a bankhitelt, és ez az eset a Burkart-Ellingsen-elmélet „közepes vagyon” esete. A közepes és kisméretűek kategóriájában a hitelek és a szállítók között szignifikáns kiegészítő kapcsolatot találtunk a nem bankhitel-korlátos cégekre. A KZ-, WW-mutatók itt sem múködtek jól, egyedül a CLEARY dummy interakciója szignifikáns. A mikrovállalkozásoknál (amelyek feltehetőleg mindkét formában korlátosak) nem találtunk kapcsolatot ott, ahol nem éles a banki korlát, és kiegészítő viszonyt találtunk ott, ahol ez éles. Ez az eset megfeleltethető a Burkart-Ellingsen-modell „kis vagyon” esetének leírásával.

\begin{tabular}{|c|c|c|c|}
\hline \multicolumn{4}{|l|}{$\begin{array}{l}\text { 9. táblázat } \\
\text { A részmintás elem }\end{array}$} \\
\hline & \multicolumn{3}{|c|}{ Vagyon (EBIT/Asset) } \\
\hline & \begin{tabular}{|c|} 
Kicsi $(<0 \%)$ \\
(van kereskedelmihitel- \\
korlát)
\end{tabular} & $\begin{array}{l}\text { Közepes (0-14\%) } \\
\text { (nincs } \\
\text { kereskedelmihitel- } \\
\text { korlát) }\end{array}$ & $\begin{array}{c}\text { Nagy (>14\%) } \\
\text { (nincs } \\
\text { kereskedelmihitel- } \\
\text { korlát) }\end{array}$ \\
\hline $\begin{array}{l}\text { Általában } \\
\text { (ha a szétválasztás } \\
\text { alapja pusztán az EBIT/ } \\
\text { Asset) }\end{array}$ & erős kiegészítő* & kiegészítő & nincs kapcsolat* \\
\hline $\begin{array}{l}\text { Hitelkapacitás-korlátos } \\
\text { (külön mérve) }\end{array}$ & erős kiegészítő* & $\begin{array}{c}\text { kiegészítö* } \\
\text { (nem robusztus) }\end{array}$ & $\begin{array}{c}\text { (a modellben nem } \\
\text { értelmezhető ez } \\
\text { a kategória) }\end{array}$ \\
\hline \multirow[t]{3}{*}{$\begin{array}{l}\text { Nem korlátos } \\
\text { (külön mérve) }\end{array}$} & $\begin{array}{l}\text { (a modellben nem } \\
\text { értelmezhető ez } \\
\text { a kategória) }\end{array}$ & $\begin{array}{l}\text { (a modellben nem } \\
\text { értelmezhető ez } \\
\text { a kategória) }\end{array}$ & nincs kapcsolat* \\
\hline & \multicolumn{3}{|c|}{ Vállalatméret } \\
\hline & Mikro & Kicsi/Közepes & Nagy \\
\hline Hitelkapacitás-korlátos & kiegészítő & $\begin{array}{c}\text { kiegészítő } \\
\text { (nem robusztus) }\end{array}$ & helyettesítő \\
\hline Nem korlátos & nincs kapcsolat & $\begin{array}{c}\text { kiegészítő } \\
\text { (nem robusztus) }\end{array}$ & helyettesítő \\
\hline
\end{tabular}


A 9. táblázatban összefoglaljuk a tesztek alapján kapott bank-szállító viszonyt az egyes esetekre lebontva.

Az empirikus vizsgálattal kapcsolatosan néhány módszertani korlát is megfogalmazódott, amelyet későbbi kutatásokban érdemes lehet fejleszteni. Érdemes lenne a magyar adatokon elkészíteni a Kaplan-Zingales-, Withed-Wu-, valamint a Cleary-indexeket, és ez alapján besorolni a magyar cégeket, vélhetően konzisztensebb becsléseket kapnánk, mint a mostani esetben. A besorolási eljárásokkal szemben azonban az amerikai adatokra építő szakirodalom is megosztott. Az sem biztos, hogy az átlagos jövedelmezőség jól ragadja meg az elméleti modellben szereplő vagyon változót. Bár más változók szerinti bontásban is hasonló eredményeket kaptunk a kutatás előzményei során, nem gondoljuk, hogy csupán egy elemből álló mutató képes lehet jól szeparálni. Valamelyest javított a helyzeten, ha a vállalati méretet is figyelembe vettük. Ezért a jövőbeli kutatásokban érdemes lehet a Burkart-Ellingsen-modell alapján egy saját kereskedelmihitel-korlátosság indexet készíteni a magyar adatokon, ami a Burkart-Ellingsen-modell „vagyon” változójának magyar proxyja lehetne.

\section{2. ábra \\ Egyedi hatások alakulása az időben}
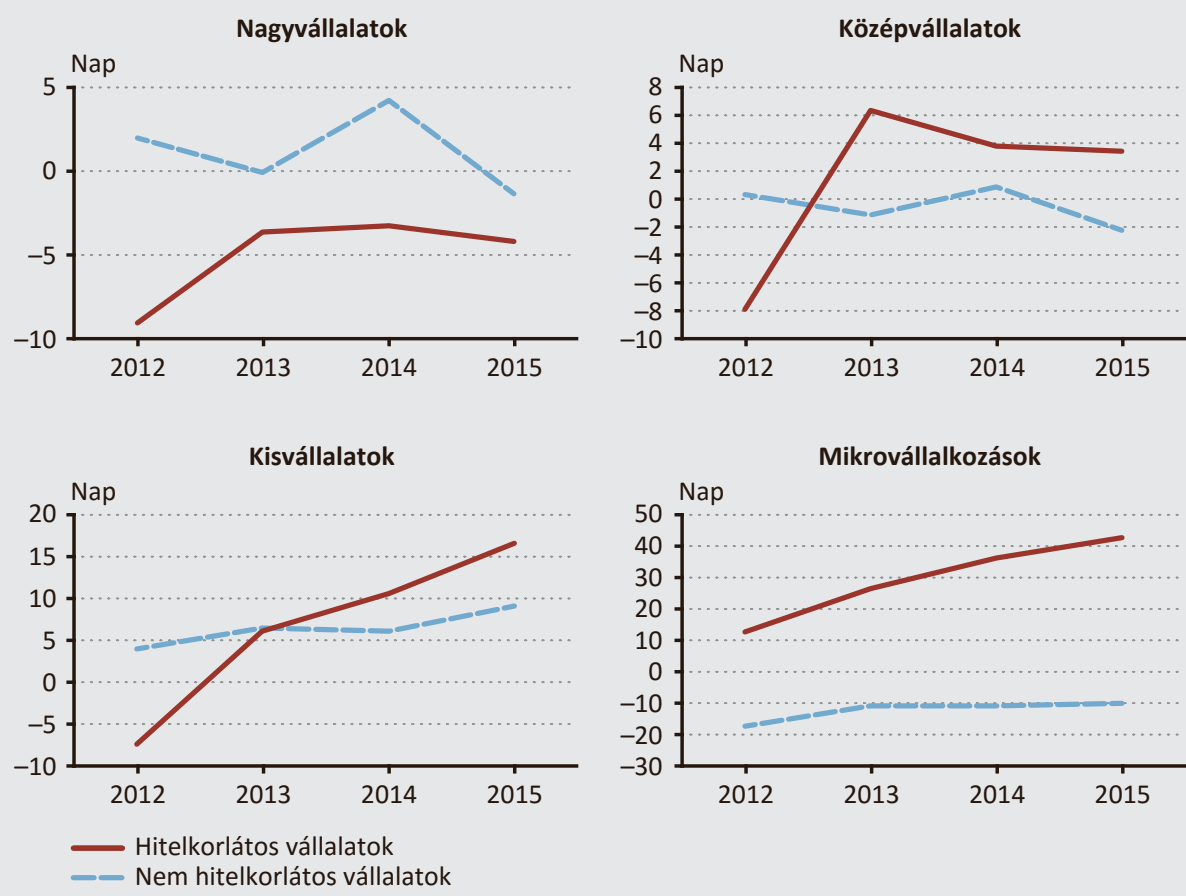

_ Hitelkorlátos vállalatok Nem hitelkorlátos vállalatok 
A (2)-es egyenlethez kapcsolódó, negyedik elemzésben térünk rá a szállítói finanszírozás trendjeire. Itt azt vizsgáljuk, hogy a cégek egyedi jellemzőinek (iparági jellegzetességek, múködési jegyek stb.) hatását kiszűrve, átlagosan hogyan változott az időben a forgási idő alakulása a bankhitelben korlátos és nem-korlátos társaságoknál. Az időbeli hatás elemzésével a konjunktúrára adott tipikus egyedi, nem aggregált reakciót, vagyis egy viselkedési mintázatot kívánunk megragadni. A becslés eredményeit a 10. táblázat tartalmazza, a ciklikusságra vonatkozó részeket a 2. ábrán illusztráljuk.

\begin{tabular}{|c|c|c|c|c|}
\hline \multicolumn{5}{|c|}{$\begin{array}{l}\text { 10. táblázat } \\
\text { A szállítói forgási sebesség időbeli alakulásának becslése }\end{array}$} \\
\hline \multirow[b]{2}{*}{ AP_COST_SALES $\times 365$} & \multicolumn{4}{|c|}{ (1A) } \\
\hline & Nagy & Közép & Kis & Mikro \\
\hline AR_SALES $\times 365$ & $\begin{array}{c}0,40^{* *} \\
(0,13)\end{array}$ & $\begin{array}{c}0,44 * * * \\
(0,12)\end{array}$ & $\begin{array}{c}0,56^{* * *} \\
(0,07)\end{array}$ & $\begin{array}{c}0,34 * * * \\
(0,03)\end{array}$ \\
\hline LOANS_ST_per_SALES & $\begin{array}{l}-19,17 \\
(30,11)\end{array}$ & $\begin{array}{c}170,07^{* * *} \\
(47,69)\end{array}$ & $\begin{array}{c}71,65^{* * *} \\
(19,32)\end{array}$ & $\begin{array}{c}33,26^{* * *} \\
(10,05)\end{array}$ \\
\hline LOANS_LT_per_SALES & $\begin{array}{c}87,99 \\
(136,89)\end{array}$ & $\begin{array}{l}191,95^{*} \\
(86,87)\end{array}$ & $\begin{array}{l}54,42 \\
(31,44)\end{array}$ & $\begin{array}{l}-3,46 \\
(10,89)\end{array}$ \\
\hline YEAR2013 & $\begin{array}{c}1,69 \\
(3,93)\end{array}$ & $\begin{array}{c}3,12 \\
(2,65)\end{array}$ & $\begin{array}{c}4,99 * * * \\
(1,46)\end{array}$ & $\begin{array}{l}5,06 \\
(2,88)\end{array}$ \\
\hline YEAR2014 & $\begin{array}{l}-2,79 \\
(3,74)\end{array}$ & $\begin{array}{c}4,19 \\
(3,54)\end{array}$ & $\begin{array}{c}6,83 * * * \\
(1,78)\end{array}$ & $\begin{array}{c}3,11 \\
(3,53)\end{array}$ \\
\hline YEAR2015 & $\begin{array}{l}1,92 \\
(4,63)\end{array}$ & $\begin{array}{l}-0,25 \\
(4,35)\end{array}$ & $\begin{array}{c}9,25^{* * *} \\
(2,46)\end{array}$ & $\begin{array}{c}3,67 \\
(3,77)\end{array}$ \\
\hline D.KZ.constr & $\begin{array}{c}-9,07^{*} \\
(4,53)\end{array}$ & $\begin{array}{l}-7,92 \\
(6,35)\end{array}$ & $\begin{array}{l}-7,43 \\
(4,84)\end{array}$ & $\begin{array}{c}12,21^{*} \\
(5,83)\end{array}$ \\
\hline D.KZ.unconstr & $\begin{array}{c}2,01 \\
(4,74)\end{array}$ & $\begin{array}{c}0,28 \\
(3,41)\end{array}$ & $\begin{array}{c}3,98 \\
(2,44)\end{array}$ & $\begin{array}{c}-17,42^{* * *} \\
(3,73)\end{array}$ \\
\hline YEAR2013:D.KZ.constr & $\begin{array}{c}3,74 \\
(5,66)\end{array}$ & $\begin{array}{l}11,07 \\
(6,56)\end{array}$ & $\begin{array}{l}8,51 . \\
(4,64)\end{array}$ & $\begin{array}{c}8,62 \\
(5,42)\end{array}$ \\
\hline YEAR2014:D.KZ.constr & $\begin{array}{c}8,54 \\
(5,64)\end{array}$ & $\begin{array}{c}7,42 \\
(4,84)\end{array}$ & $\begin{array}{l}11,18^{*} \\
(4,65)\end{array}$ & $\begin{array}{c}20,35^{* *} \\
(6,83)\end{array}$ \\
\hline YEAR2015:D.KZ.constr & $\begin{array}{c}2,91 \\
(7,66)\end{array}$ & $\begin{array}{l}11,57 . \\
(7,02)\end{array}$ & $\begin{array}{l}14,83^{*} \\
(6,94)\end{array}$ & $\begin{array}{c}26,36^{* *} \\
(9,17)\end{array}$ \\
\hline YEAR2013:D.KZ.unconstr & $\begin{array}{l}-3,73 \\
(5,45)\end{array}$ & $\begin{array}{l}-4,60 \\
(3,55)\end{array}$ & $\begin{array}{l}-2,58 \\
(2,06)\end{array}$ & $\begin{array}{c}1,67 \\
(4,03)\end{array}$ \\
\hline YEAR2014:D.KZ.unconstr & $\begin{array}{c}4,96 \\
(6,27)\end{array}$ & $\begin{array}{l}-3,62 \\
(3,46)\end{array}$ & $\begin{array}{c}-4,77^{*} \\
(2,30)\end{array}$ & $\begin{array}{c}3,62 \\
(4,50)\end{array}$ \\
\hline YEAR2015:D.KZ.unconstr & $\begin{array}{l}-5,29 \\
(5,90)\end{array}$ & $\begin{array}{l}-2,31 \\
(5,32)\end{array}$ & $\begin{array}{l}-4,20 \\
(2,83) \\
\end{array}$ & $\begin{array}{c}3,40 \\
(4,82) \\
\end{array}$ \\
\hline $\operatorname{lag}($ LOGASSET) & $\begin{array}{l}-6,79 \\
(4,12)\end{array}$ & $\begin{array}{c}-20,08^{* *} \\
(6,99)\end{array}$ & $\begin{array}{c}-31,20 * * * \\
(7,21)\end{array}$ & $\begin{array}{c}-19,82^{* * *} \\
(3,80)\end{array}$ \\
\hline EBIT_per_SALES & $\begin{array}{c}14,91 \\
(10,99)\end{array}$ & $\begin{array}{l}-23,91 \\
(16,35)\end{array}$ & $\begin{array}{l}-27,63^{*} \\
(10,97)\end{array}$ & $\begin{array}{l}-3,42 \\
(3,27)\end{array}$ \\
\hline
\end{tabular}




\begin{tabular}{|c|c|c|c|c|}
\hline $\begin{array}{l}\text { 10. táblázat } \\
\text { A szállítói forgási sebess }\end{array}$ & seli alakul & nak becslé & & \\
\hline & & & & \\
\hline AP_COST_SALES × 365 & Nagy & Közép & Kis & Mikro \\
\hline ROE & $-6,79$ & 5,70 & $-4,80$ & $7,14^{*}$ \\
\hline & $(4,16)$ & $(4,03)$ & $(4,18)$ & $(2,84)$ \\
\hline COVERAGE_RATIO & 0,01 & 0,01 & 0,01 . & $0,01^{*}$ \\
\hline & $(0,01)$ & $(0,01)$ & $(0,00)$ & $(0,00)$ \\
\hline lag(LEVERAGE) & 30,72 & 3,05 & $59,10 * * *$ & 14,91 . \\
\hline & $(18,66)$ & $(25,04)$ & $(15,64)$ & $(8,25)$ \\
\hline lag(CURRENT) & 0,03 & 0,37 & 0,19 & $0,60^{*}$ \\
\hline & $(1,88)$ & $(0,57)$ & $(0,79)$ & $(0,27)$ \\
\hline lag(CASH_per_SALES) & $292,14 * * *$ & 1,81 & 18,86 & $6,27^{* *}$ \\
\hline & $(85,81)$ & $(13,33)$ & $(9,76)$ & $(2,34)$ \\
\hline lag(CAPEX_per_SALES) & $222,38 *$ & 3,22 & $-11,66$ & $-4,37$ \\
\hline & $(86,39)$ & $(40,23)$ & $(7,17)$ & $(3,46)$ \\
\hline SALES_GROWTH & $-10,26$. & $-2,98$ & $-3,48$ & $-8,09 * * *$ \\
\hline & $(6,06)$ & $(3,58)$ & $(3,47)$ & $(1,62)$ \\
\hline DIVIDEND_RATIO & 0,54 & 0,82 & 0,02 & $-0,00 * * *$ \\
\hline & $(0,41)$ & $(0,73)$ & $(0,01)$ & $(0,00)$ \\
\hline $\mathrm{N}$ & 235 & 4432 & 13739 & 24000 \\
\hline $\mathrm{n}$ & 68 & 1332 & 4352 & 8790 \\
\hline $\mathrm{T}$ & 2012-2015 & $2012-2015$ & $2012-2015$ & 2012-2015 \\
\hline $\mathrm{R}^{2}$ & 0,7289 & 0,3613 & 0,2706 & 0,0748 \\
\hline
\end{tabular}

Megjegyzés: ${ }^{* *} p<0,001 ;{ }^{* *} p<0,01 ;{ }^{*} p<0,05 ; \cdot p<0,1$; míg a változók közötti interakciót ':' karakter jelöli.

A becslési együtthatók a nagy- és középvállalatok tekintetében nem lettek statisztikailag szignifikánsak, így az eredményeket elsősorban a kis- és a mikrovállalkozásokra tudjuk értelmezni, bár minden kategóriát megjelenítünk. Az ábrák bázisa a be nem kategorizált vállalatok 2012-es átlagos szállítói forgási ideje. Az ábrákon az ettől való eltéréseket jelenítjük meg típusonként.

A becsült együtthatók alapján megállapítható, hogy a bankhitelben korlátos mikrovállalkozásoknál növekedett a szállítók forgási ideje. Mérsékeltebb növekedés 2012-ről 2013-ra ott is jelentkezett, ahol a Kaplan-Zingales-besorolás szerint a bankhitel-kapacitásaikat még nem érik el a cégek. A kisvállalkozásoknál is tapasztalható volt a növekedés a hitelkorlátos cégeknél, ami prociklikus viselkedésre utal. Ezzel ellentétben, a nem korlátos cégeknél itt nem látunk hasonló ütemú növekedést, csak stagnálást. 


\section{6. Összegzés}

A dolgozatban a szállítói finanszírozás szerepét vizsgáljuk nem pénzügyi és nem közműszolgáltató, éves beszámolójukat forintban vezető magyar vállalkozások körében. A 2010-2015 közötti periódusban a vállalatok egyaránt megtapasztalhatták a finanszírozáshoz való hozzájutás nehézségeit, majd annak enyhülését is. Arra kerestük a választ, hogy milyen relációban állt a vállalatoknál a kereskedelmi és a banki hitel használata. Az empirikus vizsgálathoz Burkart és Ellingsen (2004) elméletet hívtuk segítségül. Bár az elméletet csak részben sikerült visszaigazolni, néhány, az elmélet keretein túlmenő, a gyakorlat számára fontos megállapítást tehettünk az adatok alapján. A rövid lejáratú hitelek és a szállítótartozás között a teljes mintán kiegészítő hatást találtunk, amely akkor volt erősebb, ha a cég a bankhitel-kapacitásait jobban kihasználta. Az alacsony önerővel (ami Burkart és Ellingsen modelljében a vagyon, a statisztikai vizsgálatban az EBIT/Sales) rendelkező cégeknél erős kiegészítő viszonyt találtunk, míg a magas jövedelmezőségű cégeknél nem sikerült helyettesítő jelleget kimutatnunk. A vizsgálatot vállalati méret szerinti bontásban is megismételtük, ahol a nagyvállalatokra a helyettesítő viszony megjelent. Bár a vállalati méret nem tekinthető a vagyon proxyjának, fontosnak tartottuk dokumentálni az eltéréseket a többi méretkategóriában is. A tanulmányban - elsősorban illusztráció céljából a szállítói finanszírozás időbeli trendjét is ábrázoltuk, méret szerinti bontásban, ahol a kis- és mikrovállalkozások közül a bankhitelkorlátos cégek megnövelték, a nem korlátos cégek pedig nem változtatták meg a szállítófinanszírozás szerepét a javuló finanszírozási időszakban.

\section{Felhasznált irodalom}

Bálint Máté - Fellner Zita (2016): Hitelezési folyamatok - 2016. augusztus. https://www.mnb. hu/kiadvanyok/jelentesek/hitelezesi-folyamatok/hitelezesi-folyamatok-2016-augusztus. Letöltés ideje: 2017. augusztus 8.

Bálint Máté - Fellner Zita (2017): Hitelezési folyamatok - 2017. május. https://www.mnb.hu/ kiadvanyok/jelentesek/hitelezesi-folyamatok/hitelezesi-folyamatok-2017-majus. Letöltés ideje: 2017. augusztus 8.

Biais, B. - Gollier, C. (1997): Trade credit and credit rationing. The Review of Financial Studies, 10(4): 903-937. https://doi.org/10.1093/rfs/10.4.903

Bokor Csilla - Fellner Zita - Plajner Ádám (2014): A Növekedési Hitelprogramban felvett hitelek felhasználása és várható hatása - egy kérdőives felmérés eredménye. In.: MNB (2014): Növekedési Hitelprogram - Az első 18 hónap, MNB. https://www.mnb.hu/letoltes/ novekedesihitelprogramazelso18honap.pdf. Letöltés ideje: 2017. augusztus 8. 
Bougheas, S. - Mateut, S. - Mizen, P. (2007): The inventory channel of trade credit: Theory and Evidence. Working Paper. Department of Economics, University of Sheffield. ISSN 1749-8368.

Brennan, M. - Maksimovic, V. - Zechner J. (1988): Vendor financing. The Journal of Finance, 43(5): 1127-1141. https://doi.org/10.1111/j.1540-6261.1988.tb03960.x

Burkart, M. - Ellingsen, T. (2004): In-kind finance: a theory of trade credit. American Economic Review, 94(3): 569-590. https://doi.org/10.1257/0002828041464579

Chittenden, F. - Bragg, R. (1997): Trade credit, cash-flow and SMEs in the UK, Germany and France. International Small Business Journal, 16(1): 22-35. https://doi. org/10.1177/0266242697161002

Cleary, S. (1999): The relationship between firm investment and financial status. The Journal of Finance, 54(2): 673-692. https://doi.org/10.1111/0022-1082.00121

Csubák Tibor Krisztián - Fejes József (2014): A magyar kkv-k 21. századi banki finanszírozásának áttekintése és kiútkeresés a hitelválság csapdájából. Hitelintézeti Szemle, 13. évf. 2. sz.: 174-194.

Cunningham, R. M. (2005): Trade credit and credit rationing in Canadian firms. Bank of Canada Working Paper, No. 2004-49. https://doi.org/10.2139/ssrn.643023

Elsas, R. - Klepsch, C. (2016): How and when do firms adjust their investments toward targets? https://dx.doi.org/10.2139/ssrn.2775091

Endrész Mariann - Harasztosi Péter - Lieli Róbert (2015): A vállalati adatokon alapuló elemzések igazolják az NHP első szakaszának beruházásélénkitő hatását. MNB. https:// www.mnb.hu/letoltes/endresz-mariann-harasztosi-peter-lieli-robert-a-vallalati-adatokonalapulo-elemzesek-igazoljak.pdf. Letöltés ideje: 2017. augusztus 8.

Emery, G. W. (1984): A pure financial explanation for trade credit. Journal of Financial and Quantitative Analysis, 19(3): 271-285. https://doi.org/10.2307/2331090

Fazzari, S. M. - Petersen, B. C. (1993): Working capital and fixed investment: new evidence on financing constraints. The RAND Journal of Economics, 24(3): 328-342.

Farre-Mensa, J. - Ljungqvist, A. (2016): Do measures of financial constraints measure financial constraints? The Review of Financial Studies, 29(2): 271-308. https://doi. org/10.1093/rfs/hhv052

Ferrando A. - Mulier K. (2013): Do firms use the trade credit channel to manage growth? Journal of Banking \& Finance, 37(8): 3035-3046. https://doi.org/10.1016/j. jbankfin.2013.02.013 
Ferris, J. S. (1981): A transactions theory of trade credit use. The Quarterly Journal of Economics, 96(2): 243-270. https://doi.org/10.2307/1882390

Freixas, X. (1993): Short term credit versus account receivable financing. Economics Working Paper 27. Department of Economics and Business, Universitat Pompeu Fabra. https:// ideas.repec.org/p/upf/upfgen/27.html

García-Teruel, P. J. - Martínez-Solano, P. (2010): Determinants of trade credit: A comparative study of European SMEs. International Small Business Journal, 28(3): 215-233. https:// doi.org/10.1177/0266242609360603

Juhász Péter - Reszegi László (2017): Gátak a magyar vállalati növekedésben. Vezetéstudomány, 48. évf. 6-7. sz.: 27-38.

Kaplan, S. N. - Zingales, L. (1997): Do investment-cash flow sensitivities provide useful measures of financing constraints? The Quarterly Journal of Economics, 112(1): 169-215. https://doi.org/10.1162/003355397555163

Kling, G. - Paul, S. Y. - Gonis, E. (2014): Cash holding, trade credit and access to short-term bank finance. International Review of Financial Analysis, Vol. 32(March): 123-131. https:// doi.org/10.1016/j.irfa.2014.01.013

MNB (2015): A részvénytársasági hitelintézetek idősorai (2014.12.31-ig). https://www.mnb. hu/felugyelet/idosorok/i-penz-es-hitelpiaci-szervezetek. Letöltés ideje: 2017. augusztus 7.

MNB (2017): Pénzügyi Stabilitási Jelentés (2017. május). https://www.mnb.hu/kiadvanyok/ jelentesek/penzugyi-stabilitasi-jelentes/penzugyi-stabilitasi-jelentes-2017-majus. Letöltés ideje: 2017.augusztus 8.

Módos Dániel - Bokor Csilla - Hidasi Balázs (2014): Az NHP-ban nyújtott hitelek és a hitelfelvevő vállalatok legfontosabb jellemzői. In.: MNB (2014): Növekedési Hitelprogram, Az első 18 hónap, MNB. https://www.mnb.hu/letoltes/novekedesihitelprogramazelso18honap.pdf. Letöltés ideje: 2017. augusztus 8.

Nábelek Fruzsina (2016): Késedelmes fizetés a magyar vállalkozások körében. MKIK Gazdaságés Vállalkozáskutató Intézet. http://gvi.hu/kutatas/467/kesedelmes_fizetes_a_magyar_ vallalkozasok_koreben

Nilsen, J. H. (2002). Trade credit and the bank lending channel. Journal of Money, Credit, and Banking, 34(1): 226-253. https://doi.org/10.1353/mcb.2002.0032

Nyírő Zsanna - Hajdu Miklós (2015): A GVI 2015. januári KKV Körkép felvételének eredményei. MKIK Gazdaság- és Vállalkozáskutató Intézet. http://gvi.hu/kutatas/398/kkv_korkep_2015_ januar_javulo_uzleti_varakozasok_a_kkv_szektorban 
Petersen, M. A. - Rajan, R. G. (1997): Trade credit: theories and evidence. Review of Financial Studies, 10(3): 661-661. https://doi.org/10.1093/rfs/10.3.661

SAFE (2011): 2011 SMEs' access to finance. Survey. Analytical Report. European Commission, Enterprise and Industry. http://ec.europa.eu/DocsRoom/documents/7922/attachments/1/ translations/en/renditions/native. Letöltés ideje: 2017. augusztus 8.

SAFE (2013): 2013 SMEs' access to finance. Survey. Analytical Report. European Commission, Enterprise and Industry. http://ec.europa.eu/docsroom/documents/7864/attachments/1/ translations/en/renditions/native. Letöltés ideje: 2017. augusztus 8.

SAFE (2014): Survey on the access to finance of small and medium-sized enterprises in the euro area, October 2013 to March 2014. European Central Bank. https://www.ecb.europa. eu/pub/pdf/other/accesstofinancesmallmediumsizedenterprises201404en.pdf. Letöltés ideje: 2017. augusztus 8.

SAFE (2015): Survey on the access to finance of enterprises (SAFE). Analytical Report 2015. European Commission. http://ec.europa.eu/DocsRoom/documents/14321/attachments/1/ translations/en/renditions/native. Letöltés ideje: 2017. augusztus 8.

Schwartz, R. A. (1974): An economic model of trade credit. Journal of Financial and Quantitative Analysis, 9(4): 643-657. https://doi.org/10.2307/2329765

Smith, J. K. (1987): Trade credit and informational asymmetry. The Journal of Finance, 42(4): 863-872. https://doi.org/10.1111/j.1540-6261.1987.tb03916.x

Szúcs Nóra (2008): Lánctartozás a kereskedelmi hitelezés irodalmának tükrében. Hitelintézeti Szemle, VII. évfolyam, 4: 399-417.

Whited, T. M. - Wu, G. (2006). Financial constraints risk. Review of Financial Studies, 19(2): 531-559. https://doi.org/10.1093/rfs/hhj012

Ying, Q. - Guo, W. - Yang, T. (2014): The substitution effect of trade credit financing in an emerging economy: empirical evidence from China. In: Xu, J. - Cruz-Machado, V. - Lev, B. - Nickel, S. (eds): Proceedings of the Eighth International Conference on Management Science and Engineering Management. Advances in Intelligent Systems and Computing, vol 280, Springer, Berlin, Heidelberg, pp. 551-561. http://doi.org/10.1007/978-3-64255182-6_48 